University of Nebraska - Lincoln

DigitalCommons@University of Nebraska - Lincoln

7-25-2001

\title{
Responses of an arctic landscape to Lateglacial and early Holocene climatic changes: the importance of moisture
}

\author{
Daniel H. Mann \\ University of Alaska Fairbanks \\ Dorothy M. Peteet \\ bNASA Goddard Institute for Space Studies and Lamont Doherty Earth Observatory \\ Richard E. Reanier \\ Reanier and Associates \\ Michael L. Kunz \\ Bureau of Land Management
}

Follow this and additional works at: https://digitalcommons.unl.edu/nasapub

Part of the Physical Sciences and Mathematics Commons

Mann, Daniel H.; Peteet, Dorothy M.; Reanier, Richard E.; and Kunz, Michael L., "Responses of an arctic landscape to Lateglacial and early Holocene climatic changes: the importance of moisture" (2001). NASA Publications. 20.

https://digitalcommons.unl.edu/nasapub/20

This Article is brought to you for free and open access by the National Aeronautics and Space Administration at DigitalCommons@University of Nebraska - Lincoln. It has been accepted for inclusion in NASA Publications by an authorized administrator of DigitalCommons@University of Nebraska - Lincoln. 


\title{
Responses of an arctic landscape to Lateglacial and early Holocene climatic changes: the importance of moisture
}

\author{
Daniel H. Mann ${ }^{\mathrm{a}, *}$, Dorothy M. Peteet ${ }^{\mathrm{b}}$, Richard E. Reanier ${ }^{\mathrm{c}}$, Michael L. Kunz ${ }^{\mathrm{d}}$ \\ ${ }^{a}$ Institute of Arctic Biology and Alaska Quaternary Center, University of Alaska, Fairbanks, AK 99775, USA \\ ${ }^{\mathrm{b}}$ NASA Goddard Institute for Space Studies and Lamont Doherty Earth Observatory, Palisades, NY 10964, USA \\ ${ }^{\mathrm{c}}$ Reanier and Associates, 1807 Thirty Second Avenue, Seattle, WA 98122, USA \\ ${ }^{\mathrm{d}}$ Bureau of Land Management, 1150 University Avenue, Fairbanks, AK 99708, USA
}

Received 23 November 2000; accepted 25 July 2001

\begin{abstract}
Many of the physical and biological processes that characterize arctic ecosystems are unique to high latitudes, and their sensitivities to climate change are poorly understood. Stratigraphic records of land-surface processes and vegetation change in the Arctic Foothills of northern Alaska reveal how tundra landscapes responded to climatic changes between 13,000 and $8000{ }^{14} \mathrm{C}$ yr BP. Peat deposition began and shrub vegetation became widespread ca. $12,500{ }^{14} \mathrm{C}$ yr BP, probably in response to the advent of warmer and wetter climate. Increased slope erosion caused rapid alluviation in valleys, and Populus trees spread northward along braided floodplains before $11,000{ }^{14} \mathrm{C}$ yr BP. Lake levels fell and streams incised their floodplains during the Younger Dryas (YD) (11,000$\left.10,000{ }^{14} \mathrm{C} \mathrm{yr} \mathrm{BP}\right)$. A hiatus in records of Populus suggest that its geographic range contracted, and pollen records of other species suggest a cooler and drier climate during this interval. Basal peats dating to the YD are rare, suggesting that rates of paludification slowed. Immediately after $10,000{ }^{14} \mathrm{C}$ yr BP, lake levels rose, streams aggraded rapidly again, intense solifluction occurred, and Populus re-invaded the area. Moist acidic tundra vegetation was widespread by $8500{ }^{14} \mathrm{C}$ yr BP along with wet, organic-rich soils. Most of these landscape-scale effects of climatic change involved changes in moisture. Although low temperature is the most conspicuous feature of arctic climate, shifts in effective moisture may be the proximate cause for many of the impacts that climate change has in arctic regions. (C) 2002 Elsevier Science Ltd. All rights reserved.
\end{abstract}

\section{Introduction}

The Arctic is important to global climate because its freshwater discharge affects North Atlantic circulation (Bacon, 1998), its snow cover influences global heat budgets (Foley et al., 1994), and its soils and wetlands are potential sources for greenhouse gases (Oechel and Vourlitis, 1996). Arctic climate is naturally variable (Overpeck et al., 1997) and is sensitive to humaninduced changes (Maxwell, 1996). Although the Arctic is widely recognized as being a critical region for global climate change, the specific mechanisms by which climate change affects arctic landscapes are poorly understood.

Physical and biological processes in polar regions are assumed to be sensitive to rising temperature because the climate is cold, but in fact the critical processes remain obscure. Process studies suggest that moisture conditions are important in mediating between climatic

*Corresponding author. Tel.: + 1-907-455-6249.

E-mail address: dmann@mosquitonet.com (D.H. Mann). changes and ecosystem responses in the Arctic (Hinzman and Kane, 1992). The dramatic changes occurring in water's physical properties around the freezing point have large effects on surface energy budgets (Kane, 1996). By thawing permafrost, rising temperatures can trigger changes in groundwater flow, surface drainage, and soil thermal regime (Nelson et al., 1993; Hinzman et al., 1996). Unfortunately, moisture conditions are poorly constrained in predictive models of arctic climate (Lynch et al., 1995; Moore et al., 1998; Bartlein et al., 1998; Kattsov and Walsh, 2000).

In this paper, we use the stratigraphic archives contained in fluvial, lacustrine, hillslope, and peat deposits to infer how surficial geology, soils, permafrost, and vegetation responded to rapid climatic changes occurring between 13,000 and $8000{ }^{14} \mathrm{C}$ yr BP during the Pleistocene to Holocene $(\mathrm{P}-\mathrm{H})$ transition on the North Slope of Alaska. Results indicate that changes in moisture were the proximate causes for many of these responses, which included feedbacks among permafrost, land-surface processes and vegetation, some of which are unique to arctic regions. 


\section{Study area}

Alaska's North Slope has two major physiographic divisions, the Arctic Foothills flanking the north side of the Brooks Range and the Arctic Coastal Plain lying further north between the Arctic Foothills and the Chukchi and Beaufort Seas (Fig. 1). Our $100 \times 200 \mathrm{~km}$ study area is in the Arctic Foothills and crosses from the Brooks Range to the southern edge of the Arctic Coastal Plain. Both physiographic divisions of the North Slope are described here because their environmental histories are closely interrelated.

The Arctic Foothills are east-west trending ridges of carbonate bedrock that protrude from tundra-covered plains (Grantz et al., 1994). Permafrost is continuous north of the Brooks Range and reaches hundreds of meters in thickness (Ferrians, 1994). Much of the Arctic Foothills region has never been glaciated. Areas near the Brooks Range, including the Mesa archaeological site (Kunz and Reanier, 1994), were last glaciated during the Tertiary and early Pleistocene. During the Last Glacial Maximum (LGM), glaciers in the Brooks Range terminated along the northern range front (Hamilton, 1986).

The Arctic Coastal Plain is underlain by a broad, low relief bedrock surface that dips gently seaward. Over the last 3 million years, the sea has repeatedly transgressed and regressed across this surface, leaving a veneer of unconsolidated and interfingering marine and nonmarine deposits (Dinter et al., 1990). Prominent among the non-marine deposits are sands and silts derived from river channels and deltas. During dry intervals in the Pleistocene, these sediments were re-worked by the wind into extensive dune fields and loess belts (Carter et al., 1987; Carter, 1988). Immediately north of the study area, the Arctic Coastal Plain is underlain by the now stable Ikpikpuk Dunes, which formed a 12,000$\mathrm{km}^{2}$ sand sea during the LGM and was partly reactivated several times during the Holocene (Carter, 1981, 1993; Dinter et al., 1990; Galloway and Carter, 1993).

Marked north-south gradients in climate occur across the North Slope. July mean temperature increases from $4^{\circ} \mathrm{C}$ at Barrow to $12^{\circ} \mathrm{C}$ at Toolik Lake near the Brooks Range front (Zhang et al., 1996). Mean annual precipitation increases inland from $200 \mathrm{~mm}$ at Barrow to $320 \mathrm{~mm}$ at Toolik Lake. Throughout the region, about half of the precipitation falls as snow, which persists on the ground for more than 8 months of the year. Rainfall increases over the course of the summer with maxima accompanying cyclonic storms in July, August, and September (Kane et al., 1992). Many of these storms cross the Brooks Range from the Bering Sea (Moritz, 1979).

During summer, most of the North Slope exists in a state of waterlogged aridity. Potential evapotranspira-

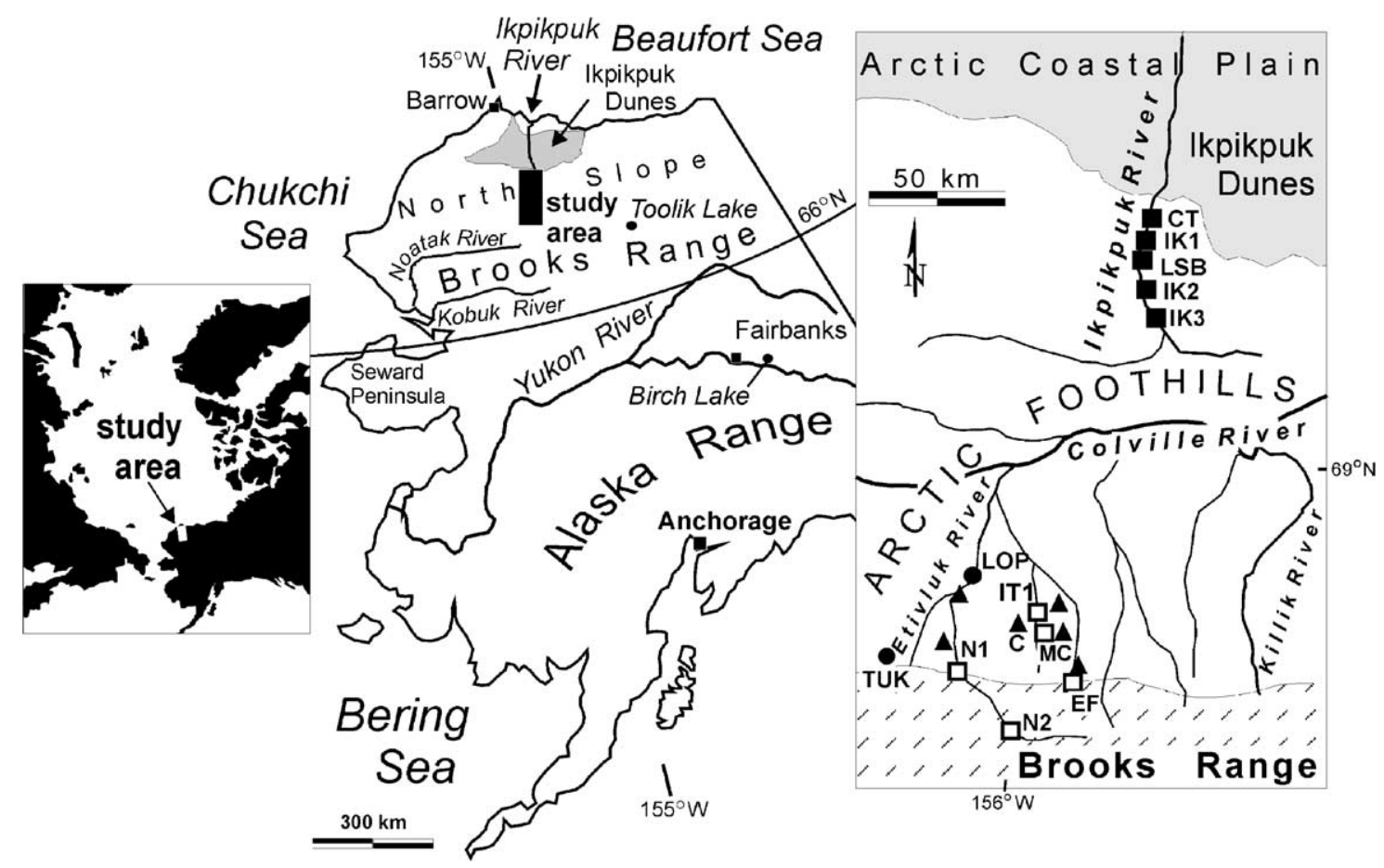

Fig. 1. The Arctic Foothills lie between the Brooks Range and the Arctic Coastal Plain on Alaska's North Slope. In the right panel, squares show locations of fluvial sections. N1 is Nigu 1, N2 is Nigu 2, EF is on the East Fork of the Etivluk River, MC is Mesa Creek section, and IT1 is on Iteriak Creek just downstream of the Mesa archaeological site. Along the Ikpikpuk River, CT is Cottonwood Bend, IK1 is Ikpikpuk 1, LSB is Little Supreme Bluff, IK2 is Ikpikpuk 2, and IK3 is Ikpikpuk 3. LOP is "Lake of the Pleistocene." Triangles represent solifluction sections; C is Cobra Gulch. TUK is Tukuto Lake. The portion of the Arctic Coastal Plain shown here includes part of the stabilized Ikpikpuk Dunes. 
tion equals or exceeds total annual precipitation (Rovansek et al., 1996), actual evapotranspiration exceeds annual runoff (Hinzman et al., 1996), and the region is classified as semi-arid by the Thornthwaite method (Patric and Black, 1968; Newman and Branton, 1972). Nonetheless, soils at many sites remain saturated throughout the summer because water tables are perched on the frozen, ice-rich substrate, and water is concentrated at the ground surface. This situation can persist because evapotranspiration is greatest in early summer before active layers fully thaw, and precipitation in late summer re-charges soil moisture at a time when evapotranspiration is low (Hinzman et al., 1996; Zhang et al., 1997).

Tundra covers the North Slope; however, a major vegetation boundary lies along the northern edge of the Arctic Foothills (Walker et al., 1998). In the Arctic Foothills, most of the vegetation is moist acidic tundra (Sphagno-Eriophoretum) dominated by dwarf shrubs (Betula nana, Ledum palustre, Salix planifolia pulchra), tussock sedges (Eriophorum vaginatum) and acidophilous mosses, among which Sphagnum species are prominent. An important point for the interpretation of pollen records is that ericaceous shrubs, Sphagnum moss, and Rubus chamaemorus (cloudberry) are characteristic of moist acidic tundra vegetation today (D. Walker et al., 1989, 1998, 2001; M. Walker et al., 1994; Shaver et al., 1996; Walker and Walker, 1996).

Moist acidic tundra vegetation typically is underlain by peaty organic horizons, leaving little mineral soil exposed at the ground surface (Bockheim et al., 1998). In the Arctic Foothills today, much of the landscape is blanketed under $5-40 \mathrm{~cm}$ of peat (Everett and Brown, 1982; Ping et al., 1998). Peat, soil material containing $>30 \%$ organic matter (Heathwaite et al., 1993), insulates the ground and creates active layers that are only $30-40 \mathrm{~cm}$ thick (Bockheim et al., 1998). Organic surface horizons acidify the soil and isolate plant roots from the mineral soil. Plant species diversity is relatively low in moist acidic tundra, plant tissues generally have low nutrient levels, and the dominant plant species are strongly defended by anti-herbivore, secondary compounds (Walker et al., 2001). These characteristics, coupled with the difficulty of walking through swampy tussocks, make moist acidic tundra a relatively poor habitat for large herbivores.

On the Arctic Coastal Plain, the dominant vegetation type is moist non-acidic tundra (Dryado-integrifoliaeCaricetum bigelowii), which is dominated by nontussock sedges (Carex bigelowii, C. membranacea, and Eriophorum triste), prostrate shrubs (Dryas integrifolia, Salix arctica, S. reticulata, and Arctuous rubra), and minerotrophic moss taxa (Walker et al., 1998). In comparison to the acidic tundra prevalent in the Arctic Foothills, moist non-acidic tundra has higher soil $\mathrm{pH}(\sim 7)$, thinner and more discontinuous organic surface horizons, deeper active layers, and a higher degree of frost disturbance (Bockheim et al., 1998; Walker et al., 2001). Plant species diversity is higher, and many plants are disturbance-adapted species with higher tissue-nutrient levels and fewer anti-herbivore compounds. Modern caribou calving grounds are located mainly in areas of non-acidic tundra (Walker et al., 2001).

Soil development on the North Slope leads towards paludification, the accumulation of waterlogged organic material on previously well-drained terrain (Bockheim et al., 1998). The waterlogging that accompanies peat accumulation influences vegetation distribution throughout the region (Walker and Walker, 1996; Walker et al., 1998), and Sphagnum mosses play a key role in paludification on the North Slope by acidifying soils, lowering soil-nutrient levels, and retaining water. In poorly drained areas, active layers are typically only $25 \mathrm{~cm}$ thick as a result of insulation by organic surface layers (Everett and Brown, 1982; Kane, 1996). In contrast, summer thaw on well-drained slopes with thin organic surface horizons can penetrate to depths of $1 \mathrm{~m}$ (Kane, 1996). Thick organic surface layers restrict frost heaving and so limit the transfer of nutrient-rich, mineral material to the soil surface (Walker et al., 2001). Organic soil horizons affect floodplain dynamics by retarding slope erosion and limiting the input of sediments to streams (Hinzman et al., 1996).

Floodplains play key roles in North Slope ecosystems. By contrast with much of the surrounding terrain, floodplain soils have deep active layers, lack thick organic horizons, and are often well drained (Ping et al., 1998). They are sites of relatively high primary productivity and plant-species diversity (Shaver et al., 1996; Walker et al., 2001). The unvegetated portions of floodplains are sources of loess, whose deposition has pervasive effects on soils and vegetation located downwind of, and adjacent to, floodplain margins (Walker and Everett, 1991). Loess and sand that are deposited on soil surfaces retard soil acidification, which reduces the rate of organic-matter accumulation and thereby maintains relatively deep and well-drained active layers.

The major runoff event of the year on the North Slope is the snowmelt flood (Arnborg et al., 1966; Carter et al., 1987; Kane, 1996); however, frozen soils restrict erosion during snowmelt, and summer rainstorms probably cause most erosion on slopes. This is also true for the beds of smaller streams where bottom-fast ice and frozen sediments armor channels during snowmelt (Scott, 1978). Where channels impinge onto higher terrain, a large part of lateral channel migration is due to thermal erosion of ice-rich permafrost (Carter et al., 1987). Most streams have wandering, gravel- and cobble-bedded channels today, though braided reaches exist in areas of aufeis accumulation, and low-order 
streams are often beaded or straight channeled between banks of peat.

Trees are absent from the North Slope except for several, widely separated stands of Populus balsamifera (balsam poplar) growing on floodplains in the Arctic Foothills (Edwards and Dunwiddie, 1985). With a mean July temperature of $10-12^{\circ} \mathrm{C}$, the Arctic Foothills lie near latitudinal treeline today (Hopkins, 1959; MacDonald et al., 2000).

\section{Previous studies}

\subsection{Glacier fluctuations}

Glaciers in the Brooks Range retreated from LGM before 14,000 ${ }^{14} \mathrm{C}$ yr BP (Hamilton and Porter, 1975; Hamilton, 1986) and underwent minor re-advances near valley heads between 13,000 and $11,500{ }^{14} \mathrm{Cyr} \mathrm{BP}$, perhaps in response to increasing winter snowfall (Hamilton, 1986). Neoglaciation began in the Brooks Range perhaps as early as $7600 \mathrm{yr}$ ago, though widespread advances did not occur until after $5000 \mathrm{yr}$ ago (Calkin, 1988). Holocene glaciation in the Brooks Range was confined to cirques and valley heads.

\subsection{Paleohydrology}

Streams and their floodplains react sensitively to climatic changes (Porter et al., 1992; Macklin, 1999; Knox, 2000), though differences in climate, vegetation, soil conditions, and watershed position can cause large variations in these responses (Knox, 1983). We know that climatic changes during the $\mathrm{P}-\mathrm{H}$ transition triggered sweeping changes in the river systems of northwestern Europe by altering effective moisture, vegetation cover, sediment supply, and permafrost conditions (Frenzel, 1995; Collins et al., 1996; Huisink, 1997; Tebbens et al., 1999; Bridgland, 2000); however, there are no previous studies of how climate change affected fluvial geomorphology on Alaska's North Slope during the $\mathrm{P}-\mathrm{H}$ transition.

Hamilton $(1980,1982,1984)$ mapped fluvial terraces along the northern front of the Brooks Range, related them to glacial advances of Tertiary and Pleistocene age, and described several stratigraphic sections, ${ }^{14} \mathrm{C}$ dates from which are incorporated in Appendix C. Dinter et al. (1990) mapped fluvial deposits of Cenozoic age on the Arctic Coastal Plain and related episodes of terrace building to times of sea-level high stands. Holocene and Pleistocene alluvial fills and terraces along streams on the North Slope have not been studied in detail, though scattered ${ }^{14} \mathrm{C}$ dates indicate that many formed between 14,000 and $8000{ }^{14} \mathrm{C}$ yr BP (Nelson and Carter, 1987; Dinter et al., 1990). The Pleistocene glaciation of the Brooks Range created a complex succession of glacier- dammed lakes with associated fluvial terraces and shorelines in the upper Noatak valley (Hamilton, 2001). Glaciation was accompanied by alluvial and aeolian activity in the Kobuk valley south of the range (Ashley and Hamilton, 1993; Hamilton and Ashley, 1993). Hamilton et al. (1988) concluded that extensive, but presently inactive, gulley networks in loess slopes near Fairbanks were cut during the last several millennia of the Pleistocene in response to a sudden increase in runoff.

In a well-dated, lake-level record from the $\mathrm{P}-\mathrm{H}$ transition at Birch Lake in interior Alaska (Fig. 1), water levels are inferred to have risen rapidly between 12,700 and $12,200{ }^{14} \mathrm{C}$ yr BP, thereafter falling back to low levels (Abbott et al., 2000). A second transgression occurred sometime between 10,600 and 10,000 ${ }^{14} \mathrm{C}$ yr BP. Between 8800 and $8000{ }^{14} \mathrm{C}$ yr BP, the lake rose to reach its modern (overflow) level.

Epstein (1995) measured deuterium in ${ }^{14} \mathrm{C}$-dated Salix-wood samples from the now inactive Ikpikpuk Dunes on the Arctic Coastal Plain. His results suggest that major fluctuations in water availability, and/or in evaporative source areas for precipitation, occurred between 12,000 and $8000{ }^{14} \mathrm{C}$ yr BP. Cellulose $\mathrm{LD}$ values were highly negative during the Younger Dryas Chronozone $\left(\sim 11,000-10,000{ }^{14} \mathrm{C}\right.$ yr BP $)$, suggesting more droughty conditions and/or a more distant evaporative source. As discussed in detail below, changes in soil moisture triggered episodic reactivations of the Ikpikpuk Dunes during the Lateglacial and Holocene (Carter, 1993; Galloway and Carter, 1993).

\subsection{Paleobotany}

The vegetation history of Alaska's North Slope during the $\mathrm{P}-\mathrm{H}$ transition is known only in outline due to the reconnaissance nature and poor dating control of pioneering studies and because of methodological problems inherent to tundra-zone palynology. Some previous studies are based on discontinuously deposited, silt and peat sediments of Holocene age (Livingstone, 1957; Colinvaux, 1964a, b; Walker et al., 1981; Eisner and Peterson, 1998). Where Pleistoceneand Holocene-aged lake sediments have been analyzed, the sampling intervals are too wide to yield temporal resolutions better than several millennia (Eisner and Colinvaux, 1990, 1992). More detailed pollen records from lake sediments are available from far northwestern Canada (Cwynar, 1982; Ritchie et al., 1983), though dating resolution is limited there also. Pollen records from lakes on the southern slopes of the Brooks Range (Brubaker et al., 1983; Anderson, 1985, 1988) span the $\mathrm{P}-\mathrm{H}$ transition, but more recent studies (Oswald et al., 1999) suggest their dating control is problematic

Accurate dating control is difficult to achieve in arctic lakes because low temperature and waterlogged soils 
allow abundant organic material to escape decay and to become incorporated in younger sediments (Schell, 1983; Abbott and Stafford, 1996). Bulk samples of lake sediment can be contaminated by old carbon derived from soils, peat, and/or carbonate bedrock within the watershed (Oswald et al., 1999). ${ }^{14} \mathrm{C}$-dating of paired samples reveals that bulk-sediment samples can be centuries to millennia older than the associated macrofossils of terrestrial plants (Abbott and Stafford, 1996; Abbott et al., 2000).

Tundra pollen records can be difficult to interpret for several reasons. Some abundant and presently diverse groups of tundra plants are impossible to identify to species using pollen characteristics. Many tundra species are ecological generalists with wide geographical ranges, limiting their usefulness in paleo-environmental interpretations (Colinvaux, 1964a; Anderson et al., 1994). Pollen accumulation rates (PARs) are of limited use for interpreting vegetation changes during the $\mathrm{P}-\mathrm{H}$ transition because sedimentation rates are typically slow, variable, and, as just described, difficult to date accurately. In sediments older than $10,000{ }^{14} \mathrm{C}$ yr BP, PAR estimates are complicated further by uncertainties in the calibration of ${ }^{14} \mathrm{C}$ yr to calendar years.

With these cautions about taxonomic/ecological resolution and age control in mind, the vegetation history of the Arctic Foothills from $\sim 19,000{ }^{14} \mathrm{C}$ yr to present can be described as follows. The work of Oswald et al. (1999) at Tukuto Lake (Fig. 1) is emphasized because it is the most carefully executed and best-dated lake-core record near our study area.

Vegetation history in the area around Tukuto Lake followed the same sequence of herb-, birch-, and alderpollen zones that is documented in other parts of eastern Beringia (Anderson and Brubaker, 1994; Edwards and Barker, 1994). In levels dating to the LGM, Poaceae (grass) is the most abundant pollen taxon (30-50\%), with less abundant Cyperaceae (sedge, $<10 \%$ ), and a variety of minor herb taxa. Oswald et al. (1999) suggest that vegetation in the Arctic Foothills at this time was xeric tundra. At levels dated sometime between the LGM and $\sim 13,000{ }^{14} \mathrm{C}$ yr BP, Poaceae percentages decline and Cyperaceae and Salix (willow) become the dominant pollen taxa. Vegetation in this transition period probably was similar to the moist non-acidic tundra now widespread on the Arctic Coastal Plain. The transition from xeric, steppe-tundra to mesic, shrub tundra was completed sometime after $12,830{ }^{14} \mathrm{C}$ yr BP. At the level of this date, Betula (birch) pollen, probably that of Betula nana/glandulosa (dwarf and shrub birch), reaches values $>20 \%$ in the pollen diagram (Oswald et al., 1999). Shrub tundra vegetation is indicative of increased summer warmth and increased effective moisture (Cwynar, 1982; Chapin et al., 1995).

The position of $\mathrm{P}-\mathrm{H}$ transition is poorly constrained in the Tukuto Lake core between levels dated to 12,800 and $7300{ }^{14} \mathrm{C}$ yr BP. Only 15 samples from this $5500{ }^{14} \mathrm{C}$ $\mathrm{yr}$ interval were analyzed for pollen, so vegetation history during the transition remains obscure. It is unclear from the plot of total PAR where in the lithostratigraphy the $\mathrm{P}-\mathrm{H}$ transition actually occurs. Pollen of Ericales (heaths) and Rubus chamaemorus first appear at levels dated between 12,800 and 7300 ${ }^{14} \mathrm{C}$ yr BP, and Oswald et al. (1999) suggest that moist acidic tundra became widespread during this period.

A diffuse peak in Populus (cottonwood) pollen occurs in the Tukuto Lake core between limiting dates of 12,800 and $7300{ }^{14} \mathrm{Cyr} \mathrm{BP}$. Elsewhere in northern Alaska, a Populus-pollen subzone is dated between $11,000{ }^{14} \mathrm{C}$ yr BP and $8000{ }^{14} \mathrm{C}$ yr BP; though the timing of its beginning and end vary by as much as $3000{ }^{14} \mathrm{C} \mathrm{yr}$ in different lakes, and there is no apparent geographical pattern to this variability (Anderson, 1988; Bartlein et al., 1995; Szeicz and MacDonald, 2001). Questions about the accuracy of the bulk-sediment ${ }^{14} \mathrm{C}$ dates make it unclear whether or not the Populus subzone was synchronous across the region. Radiocarbon dates on Populus wood at sites now beyond the present range of this species suggest that Populus trees had expanded into areas beyond their present range limits prior to 11,000 ${ }^{14} \mathrm{C}$ yr BP (references in Appendix A). Prior to this study, 15 dates on extralimital Populus wood from northern Alaska and northwestern Canada had been reported. Three of these dates fall between 11,500 and $11,100{ }^{14} \mathrm{C}$ yr BP, while the remainder fall between 9900 and $7200{ }^{14} \mathrm{C}$ yr BP.

Alnus (alder) pollen appears in the Tukuto Lake record in levels younger than $7300{ }^{14} \mathrm{C}$ yr BP. The arrival of alder probably indicates further increases in effective moisture (Oswald et al., 1999). The Alnus pollen zone represents a period of general vegetational stability near Tukuto Lake that continues to the present. Today the vegetation near the lake is dominated by moist acidic tundra with Betula, Alnus, Salix, Ericales, and Cyperaceae dominating the pollen rain, and Sphagnum the most abundant spore type (Oswald et al., 1999).

\subsection{Fossil beetles}

Beetle remains from northern Alaska and the continental shelf of the Chukchi Sea suggest that summer and winter temperatures were depressed by $2^{\circ}$ and $8^{\circ} \mathrm{C}$, respectively, during the LGM (Elias et al., 1996; Elias, 2000, 2001). Beetle remains from western Alaska indicate that temperatures had risen from ice-age to modern levels by $12,500{ }^{14} \mathrm{C}$ yr BP. A peak in warmth occurred $\sim 11,000{ }^{14} \mathrm{C}$ yr BP and was followed by a possible cooling between 11,000 and $10,000{ }^{14} \mathrm{Cyr} \mathrm{BP}$ (Elias, 2000). A beetle fauna associated with Populus wood dating to $9430{ }^{14} \mathrm{C}$ yr BP at a site on the Ikpikpuk River indicates well-drained soils and a July mean temperature $2-3^{\circ} \mathrm{C}$ higher than today (Nelson and Carter, 1987). 


\section{Methods}

Stratigraphic sections were prepared by clearing slumped material to expose undisturbed, frozen sediments. Basal peats were recovered from permafrost using a power auger. At each drill site, coring was continued until breaking a cutter tooth on rock. Particle size (Udden-Wentworth scale) of mineral sediments in Lake of the Pleistocene was determined by the pipette method; coarser sediments were analyzed by dry sieving. In both procedures, organic material and carbonates were removed using $\mathrm{H}_{2} \mathrm{O}_{2}$. Organic-matter content was estimated after loss on ignition at $500^{\circ} \mathrm{C}$. Total inorganic carbon content was measured by subsequent heating of the same samples to $1000^{\circ} \mathrm{C}$ (Dean, 1974). For pollen analysis, subsamples of 1 or $2 \mathrm{~cm}^{3}$ of sediment were prepared for analysis following standard procedures for organic-poor sediments (PALE, 1994). Pollen residues were mounted in silicon oil and counted at 400x and 1000x magnification. At least 300 grains of terrestrial pollen were counted at each level. The pollen percentages for tress, shrubs, and herbs were based on this sum. Percentages of terrestrial spores were based on the terrestrial pollen plus terrestrial spore sum, and percentages of aquatic spores were based on the terrestrial pollen plus the aquatic and spore sum. The mean number of indeterminate grains per counted level was 4.30 (s.e. $=0.35$ ). ${ }^{14} \mathrm{C}$ dates are calibrated using Calib4 (Stuiver et al., 1998).

Fluvial sections were described by mapping sedimentary units and bounding surfaces onto photographic mosaics of cutbank exposures. Stream terraces were mapped using 1:60,000- and 1:24,000-scale aerial stereo photography, and their altitudes estimated using topographic maps with contour intervals of $10-20 \mathrm{~m}$ and a surveying altimeter with an accuracy of $\pm 2 \mathrm{~m}$. Paleoflow directions were inferred from the orientations of bedform slipfaces, the strikes of scour channels, and occasionally from the orientation of woody debris. Plant macrofossils were extracted for AMS-radiocarbon dating by washing sediments through 500 - and 150 -micron sieves, examining residues under a dissecting microscope, and identifying plant parts using modern reference material. Wood identifications were made by the US Forest Service Wood Products Laboratory in Madison, Wisconsin. Populus balsamifera leaves were identified at the University of Alaska Herbarium by C. Parker and D. Murray.

\section{Results and discussion}

\subsection{Lake of the Pleistocene}

Lake of the Pleistocene (LOP) is a drained lake basin whose sediments contain a lengthy record of lake-level and vegetation changes. The basin formed as an alas valley (Yershov, 1998) in glacial-outwash terraces of middle Pleistocene age (Hamilton, 1984) (Fig. 2). Intermittent overflow probably occurred northward over a series of low sills formed by the alluvial fans of streams such as Rudivik Creek. Sediments accumulated in LOP from $>40,000$ until $\sim 5000{ }^{14} \mathrm{Cyr} \mathrm{BP}$ (Appendix B), when the basin was breached by lateral erosion of the Etivluk River. The deepest part of the basin still contains Nikivlik Lake, a 3-m deep remnant of the formerly larger lake. Today, several hundred meters of the ancient lakebed (Fig. 3) are cross-sectioned by the Etivluk River, revealing a detailed lithostratigraphic sequence containing abundant twigs suitable for AMS- ${ }^{14} \mathrm{C}$ dating. The LOP sections lack the sedimentary facies diagnostic of thaw-lake basins (Hopkins and Kidd, 1988; Murton, 1996), indicating that the sediments studied here have not been disturbed by thermokarst processes.

\subsubsection{Water-level history in LOP}

Striking features of the Holocene portions of the LOP sections are $0.5-2 \mathrm{~cm}$ thick layers of flat-lying willow leaves and twigs, which are laterally continuous for 20 $100 \mathrm{~m}$ and occur sporadically in vertical section (Fig. 3). These plant-debris layers contain sand and occasional granules and sometimes comprise the basal portions of

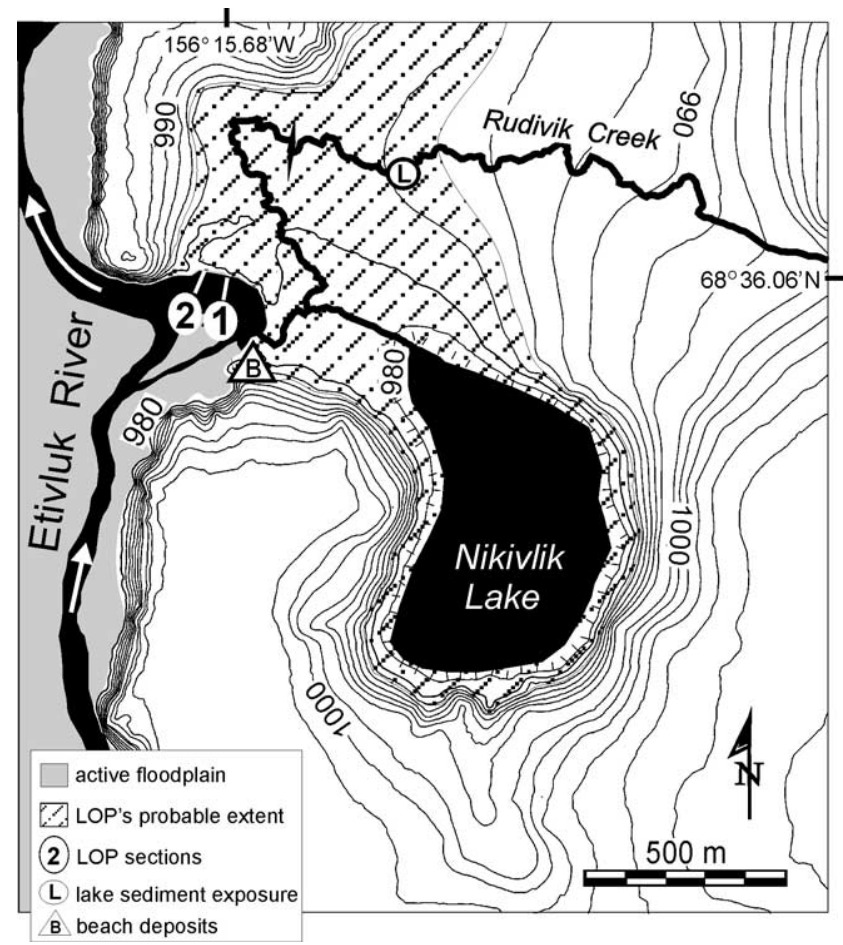

Fig. 2. Part of the former drainage basin of LOP. The $2 \mathrm{~m}$ contour interval comes from a laser-transit survey. The extent of the former lake is based on an exposure of lake sediments along Rudivik Creek and a sandy beach deposit on the southern shore. Solifluction has obscured the ancient shorelines throughout the basin. 


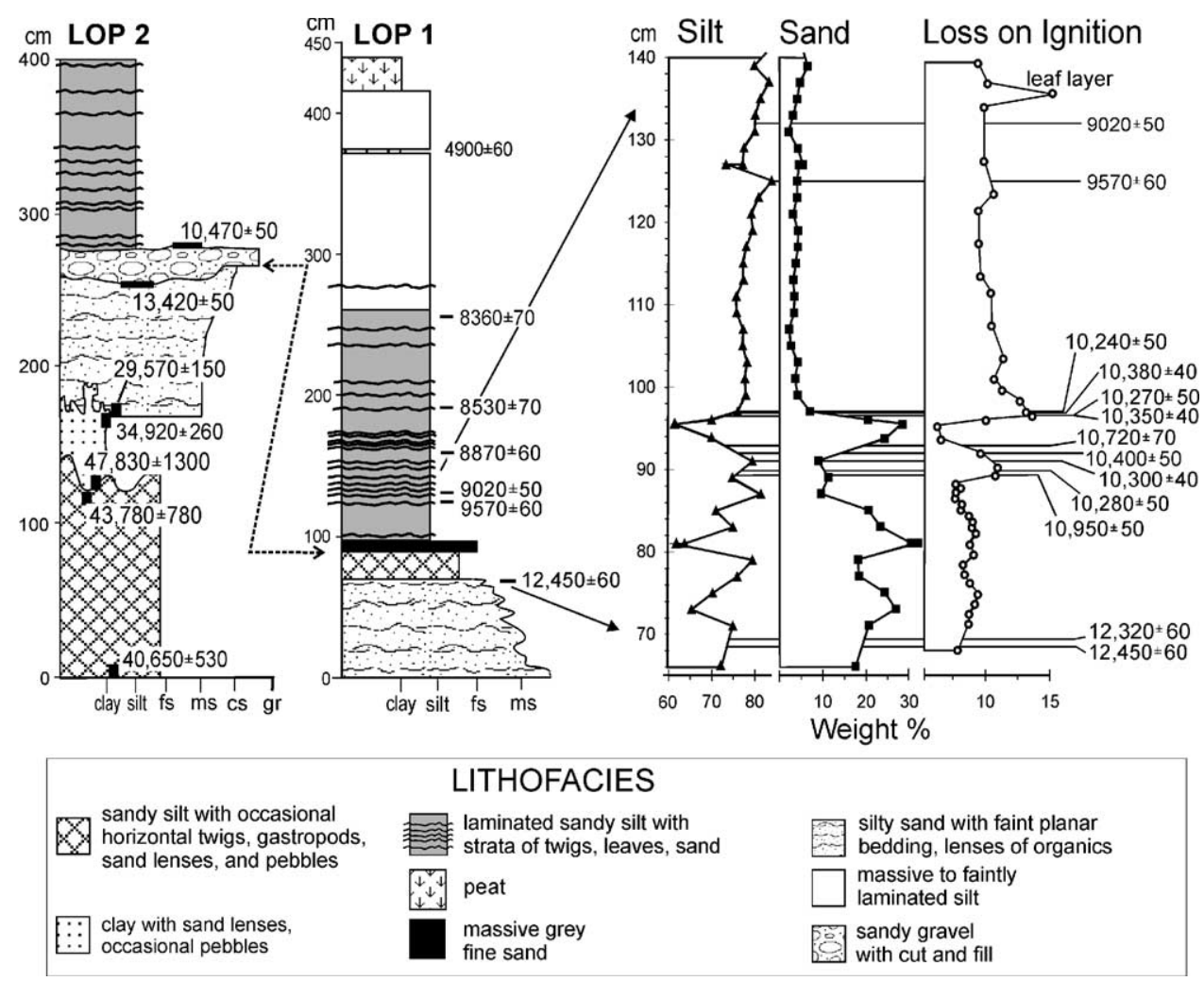

Fig. 3. Stratigraphy of LOP. Section LOP2 is $50 \mathrm{~m}$ west of LOP1 and closer to the basin's margin. "Fs" is fine sand, "ms" is medium sand, "cs" is coarse sand, and "gr" is gravel. All ${ }^{14} \mathrm{C}$ dates were obtained by the AMS method on willow and birch twigs.

normally graded beds capped by silts and clays. We interpret these beds as recording ancient sedimentation limits, the border zones between wave-scoured shallows and deeper, still water where fine sediments are deposited (Dearing, 1997; Verschuren, 1999). Similar plant-debris layers occur today in Nikivlik Lake, where we studied them using a surface-sediment sampler and by wading barefoot.

Presently in both summer and winter, abundant plant debris is blown from lee-slope willow thickets into Nikivlik Lake. After initial deposition near shore, waterlogged twigs and leaves are transported into deeper water during high-wave events, where they accumulate at depths just below wave base (cf., Sly, 1978). As the water calms, suspended silt and clay settle out on top of the plant debris. Today, zones of multilayered, muddy twigs and leaves occur on the bottom of Nikivlik Lake in water depths between 0.2 and $1 \mathrm{~m}$. If water depth increased and the lake expanded, the zone of abundant plant debris would migrate landward. In vertical sections through the silt- and clay-rich Holocene sediments of LOP, units with few or no plant-debris layers indicate relatively deep water, while those with numerous plant-debris layers indicate shallow water.

Changes in particle size, organic content, and debrislayer frequency (Fig. 3) indicate that water levels fluctuated markedly in LOP. Low sedimentation rates and sandy sediments suggest that the lake was inter- mittently dry during the LGM. By $12,450{ }^{14} \mathrm{C}$ yr BP, water level had risen sufficiently that sandy silts containing gastropods and algal cells were deposited. In the LOP1 section, organic content increased shortly before $11,000{ }^{14} \mathrm{C}$ yr BP then declined to low values between 10,900 and $10,200{ }^{14} \mathrm{C}$ yr BP during the Younger Dryas (YD). ${ }^{14} \mathrm{C}$ dates within this interval show the age reversals that are characteristic of the YD Chronozone (Björck et al., 1996). In outcrop, the YD corresponds to $3-5 \mathrm{~cm}$ of fine sand that is laterally continuous for $>100 \mathrm{~m}$, and which probably records a low lake stand. Alternately, the sand layer could record a turbidity flow resulting from a landslide in the drainage basin. The latter hypothesis is rejected because the sequence of ${ }^{14} \mathrm{C}$ dates during the YD Chronozone in LOP1 follow a characteristic pattern found at other sites in the northern hemisphere (Hajdas et al., 1998), indicating that sedimentation proceeded slowly but continuously over the $\sim 1000{ }^{14} \mathrm{C}$-yr duration of the YD.

In the LOP2 section, which lies $50 \mathrm{~m}$ closer to the basin margin, $10-20 \mathrm{~cm}$ of medium sand with pebble lags and an erosive lower contact probably represents a beach formed during the YD low stand of the lake (Fig. 3). Altitudinal differences between the two sections are obscured by deformation caused by epigenetic ice wedges, which formed in the sediments after lake drainage $\sim 5000{ }^{14} \mathrm{C}$ yr BP. Deposition of organic silts and clays resumed after $\sim 10,200{ }^{14} \mathrm{C}$ yr BP as water 
levels rose. The distribution of plant-debris layers suggests that the lake deepened between 10,000 and $9600{ }^{14} \mathrm{C}$ yr BP, but then shallowed until $\sim 8600$ ${ }^{14} \mathrm{C}$ yr BP, after which it deepened again.

\subsubsection{Vegetation history during the}

\section{Pleistocene-Holocene $(\mathrm{P}-\mathrm{H})$ transition in $\mathrm{LOP}$}

The lowest two samples in the LOP1 section are dominated by Cyperaceae pollen $(40-60 \%)$ with minor amounts of Poaceae (grass) (8\%) and Juniperus (juniper) $(1 \%)$ pollen (Fig. 4). Intensive sampling of the section begins at the $68-\mathrm{cm}$ level between two twigs that yield concordant ages of 12,450 and $12,320{ }^{14} \mathrm{C} \mathrm{yr} \mathrm{BP}$. At this level, Betula (birch) pollen has already increased to $20 \%$, which is its percentage in modern pollen-rain samples from the northern range limit of B. nana/ glandulosa in Alaska (Anderson and Brubaker, 1986, 1994). We infer that Betula shrubs had become widely established around LOP at or shortly before 12,400 ${ }^{14} \mathrm{C}$ yr BP. Populus pollen reach $4 \%$, this taxa's all-time high in the diagram, at the level of the $12,320 \mathrm{yr}$ date, and cells of the alga Pediastrum begin an abrupt rise at the same level, suggesting the LOP basin had filled with water. All these changes are suggestive of an increase in effective moisture within the several centuries preceding $12,400{ }^{14} \mathrm{C}$ yr BP.

Several subtle changes occur in the LOP pollen diagram between the $87-$ and $95-\mathrm{cm}$ levels in the part of the section corresponding to the YD. Populus pollen disappear immediately above the level dated to $10,900{ }^{14} \mathrm{C}$ yr BP and do not re-appear in the diagram until slightly above the $100-\mathrm{cm}$ level, which lies between limiting ages of 10,240 and $9570{ }^{14} \mathrm{Cyr} \mathrm{BP}$ (Fig. 4). Populus pollen decays readily, and its absence from the sand unit could be an artifact of preservation; however, Populus is also absent from lowest $5 \mathrm{~cm}$ of silty sediments immediately overlying the sand unit. We hypothesize that the temporary disappearance of Populus indicates a reduction in the extent of its preferred floodplain habitat due to changes in fluvial regimes (see below) and perhaps because of cooler, drier summers.

Changes in the percentages of several other taxa hint at drier conditions during the YD. A peak in Juniperus pollen percentages occurs at levels dating to 10,950 ${ }^{14} \mathrm{C}$ yr BP. Today, Juniperus grows at xeric sites throughout Alaska. The cause of a brief spike in Betula pollen at levels corresponding to the YD Chronozone remains unexplained. Artemisia (sage) and Poaceae pollen and Selaginella sibirica (spikemoss) spores reach their highest abundance in the entire record during the YD Chronozone. Selaginella sibirica is common today on windblown, south-facing slopes (Walker et al., 1989). Pediastrum briefly reached high abundance during the YD, possibly suggesting lower water levels (Anderson and Brubaker, 1986; Bigelow and Edwards, 2001). A brief decline in Cyperaceae percentages and increases in Artemisia, Poaceae, Juniperus, Selaginella, and Pediastrum are all consistent with drier conditions during this interval. Similar patterns of change by some of these same taxa have been interpreted as evidence for drier and cooler conditions during the $\mathrm{YD}$ in the Alaska Range (Bigelow and Edwards, 2001).

Changes in pollen and spore percentages at levels dating between 10,240 and $8530{ }^{14} \mathrm{C} \mathrm{yr} \mathrm{BP}$ are suggestive of increasing effective moisture. Ericales percentages rise gradually in levels younger than $12,320{ }^{14} \mathrm{C}$ yr BP, but they do not exceed $5 \%$, their percentage in the modern pollen rain on the North Slope (Anderson and Brubaker, 1986), until the level dated to $9570{ }^{14} \mathrm{C}$ yr BP.

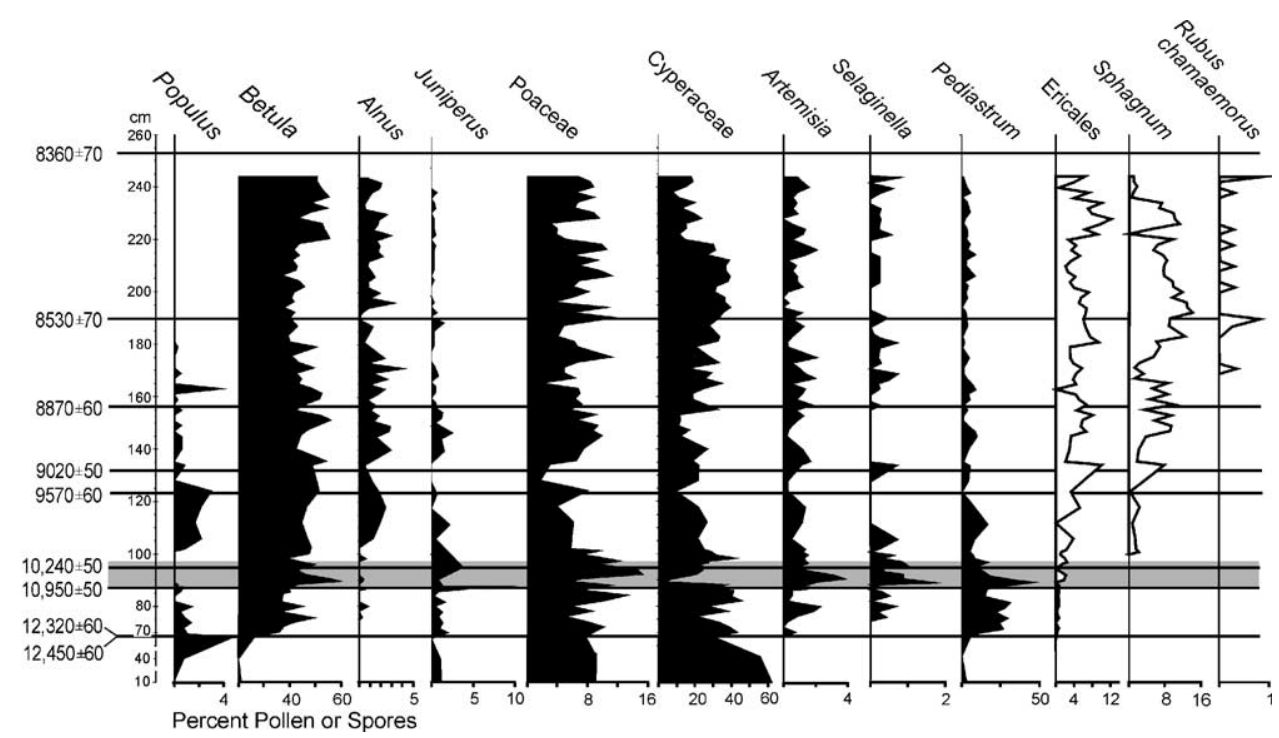

Fig. 4. Percentage pollen and spore diagram from LOP1. White curves show taxa associated with paludification. ${ }^{14} \mathrm{C}$ dates from LOP1 section are shown in Fig. 3. The YD Chronozone is shaded. 
Sphagnum first reaches its modern percentages $(10 \%)$ near the level dated to $9020{ }^{14} \mathrm{C}$ yr BP. Both Ericales and Sphagnum are indicator taxa of moist acidic tundra (Walker et al., 1998). Another indicator of this vegetation type is Rubus chaemaemorus (cloudberry), whose pollen first appears in the diagram at levels dating to between 8870 and $8530{ }^{14} \mathrm{C}$ yr BP.

Slight declines occur in Juniperus, Poaceae, Artemisia, Selaginella, and Pediastrum percentages in samples postdating $10,240{ }^{14} \mathrm{C}$ yr BP (Fig. 4). Populus disappears entirely at levels younger than $8500{ }^{14} \mathrm{C}$ yr BP. Alnus pollen first reaches values of several percent between 10,240 and $9570{ }^{14} \mathrm{C}$ yr BP, a percentage maintained through the remainder of the diagram. Such low percentages make it difficult to ascertain when Alnus first arrived near LOP. We conclude that the modern tundra vegetation, accompanied by its poorly drained, organic soils, was probably established in the study area between 9000 and $8500{ }^{14} \mathrm{C}$ yr BP.

\subsection{Extralimital Populus trees}

New and previously obtained ${ }^{14} \mathrm{C}$ dates on Populus wood and leaves from northern Alaska and northwestern Canada suggest this species expanded into areas beyond its present range limits twice during the latest Pleistocene and earliest Holocene. We dated two Populus logs and two Populus balsamifera leaves from fluvial sediments along the Ikpikpuk River. The two logs and one of the leaves dated between 9270 and 9720 ${ }^{14} \mathrm{C}$ yr BP, and the other leaf dated to $10,940{ }^{14} \mathrm{C}$ yr BP (Appendix A). Four previously reported dates on cottonwood from the Ikpikpuk River range from 8710 to $9540{ }^{14} \mathrm{C}$ yr BP (Nelson and Carter, 1987). Of the ten samples of extralimital Populus wood reported by Hopkins et al. (1981), three dated to between 11,100 and $11,500{ }^{14} \mathrm{Cyr} \mathrm{BP}$, and the remainder between 7270 and $9940{ }^{14} \mathrm{Cyr} \mathrm{BP}$. One of the pre-11,000 year dates was from the Nigu River, probably from the Nigu 1 section described below. These results suggest that Populus expanded its range into the present tundra region twice, first between 11,500 and $10,900{ }^{14} \mathrm{C}$ yr BP and then again between 10,000 and $7200{ }^{14} \mathrm{C}$ yr BP.

We speculate that changes in fluvial geomorphic regimes influenced the geographic distribution of Populus balsamifera on the North Slope during the $\mathrm{P}-$ $\mathrm{H}$ transition. In the boreal forest, P. balsamifera is an early successional species that colonizes recently disturbed soils (Payette, 1993). In Alaska, this species grows mainly on river bars, where it forms large stands during the first 150 years of primary succession (Viereck, 1970; Viereck and Little, 1975). In the Arctic Foothills, relict stands of Populus now occupy recently deposited fluvial terraces, where they reproduce largely by root sprouting (Murray, 1980; Edwards and Dunwiddie, 1985). As described below, periods of stream aggrada- tion in the Arctic Foothills occurred between 12,000 and $11,000{ }^{14} \mathrm{C}$ yr BP and again between 10,000 and 8700 ${ }^{14} \mathrm{C}$ yr BP. These two periods of aggradation created large areas of newly stabilized gravel bars suitable for Populus establishment. Newly deposited gravel bars were more rare during periods of channel incision. Perhaps the abundance and northerly extent of $P$. balsamifera varied according to the availability of its gravel-bar habitat.

\subsection{Paludification of the Arctic Foothills and Arctic Coastal Plain}

Dates on basal organic sediments from permafrost cores and stream cuts describe the timing of paludification in the study area (Appendix C). In general, two different types of basal organics occur in the tundra zone. The first are true basal organics (TBO), the lowest deposits of nonaquatic plant remains found in stratigraphic sections composed mainly of peat, which are immediately underlain by mineral sediments. The second are lowest cryoturbated organics (LCO) in permafrost, fragments of organic material that are now below the modern active layer. LCO is emplaced by cryoturbation, which churns organic matter deep into the active layer, where eventually it may become sequestered in permafrost (Ping et al., 1998). Ages of LCO samples are minimum-limiting dates on organicmatter accumulation at a site. We interpret TBO ages as absolute dates on the onset of organic accumulation.

To describe the paludification history of a topographically and pedologically representative portion of the Arctic Foothills, 19 TBO and LCO dates were obtained from a $10-\mathrm{km}^{2}$ area around the Mesa archaeological site (Kunz and Reanier, 1994). Auger sites were positioned along toposequences extending from rocky, frost-disturbed interfluves to alluvial toeslopes. The oldest dates range from 11,000 to $12,000{ }^{14} \mathrm{C}$ yr BP and come from TBO samples beneath midslope water tracks and toeslopes (Fig. 5, Appendix C). Soils on the interfluve southeast of the Mesa began storing carbon as early as $8400{ }^{14} \mathrm{C}$ yr BP, the AMS-radiocarbon age of a birch twig within a clump of LCO. Today this site is covered by moist acidic tundra growing among ice-wedge polygons. The wide scatter in the ages of ${ }^{14} \mathrm{C}$-dated LCOs from convex slopes and interfluves probably results from the churning of silty soils there by frost heaving. Gravel prevented drilling deeper than 1-2 $\mathrm{m}$ at most of these upland sites. Stratigraphic sections provide additional information on the timing of paludification in the Arctic Foothills (Appendix C). The oldest TBO samples date to $\sim 12,600{ }^{14} \mathrm{C}$ yr BP and occur on toeslopes in headwater stream valleys.

Data collected by other workers elsewhere on the North Slope yield further insights into the regional time course of paludification. In compiling these data, we 


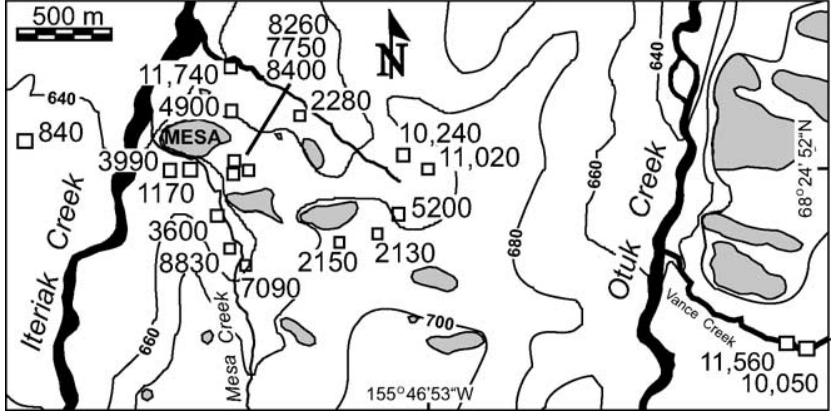

Fig. 5. AMS dates on basal organics from representative topographic positions near the Mesa archaeological site. The gray patches are the locations of either bedrock outcrops or the gravel surfaces of early Pleistocene stream terraces.

excluded dates on basal organics from sites where geomorphic evidence suggested a priori that the age of the underlying landform was $<14,000{ }^{14} \mathrm{C} \mathrm{yr} \mathrm{BP}$, as for example, Holocene-aged beach ridges and stream terraces. The goal is to identify when climate and soil conditions allowed paludification to occur. Hence we made exceptions to the 14,000 -yr rule in the cases of sand dunes, where paludification could have caused dune stabilization, and at sites affected by solifluction lobes that overlie peat horizons (see below). Excluded from Appendix $\mathrm{C}$ are any dates on basal organics that accumulated in thaw lake basins (see Murton, 1996 for the identification of such sediments), dates whose 1sigma errors are $>200 \mathrm{yr}$, and dates from uncertain stratigraphic contexts.

Dates on TBOs from elsewhere on the North Slope (Appendix C) suggest that widespread peat accumulation occurred between $\sim 12,500$ and $11,000{ }^{14} \mathrm{C}$ yr BP. Frequencies of both TBO and LCO dates decline between 11,000 and $10,000{ }^{14} \mathrm{Cyr} \mathrm{BP}$, probably reflecting a slowdown in paludification. Numerous TBO and LCO samples date to the interval $10,000-9000{ }^{14} \mathrm{C}$ yr BP, after which their numbers decline again. Together, basal-peat dates from the North Slope imply that primary productivity first surpassed decomposition $\sim 12,500{ }^{14} \mathrm{C}$ yr BP, but only in topographic low points. Paludification slowed during the YD Chronozone, then resumed after $10,000{ }^{14} \mathrm{C}$ yr BP. By $\sim 8500{ }^{14} \mathrm{C}$ yr BP, organic surface horizons probably had assumed their present wide distribution across the region.

\subsection{Solifluction in the Arctic Foothills at the $P-H$ boundary}

At least one widespread episode of increased solifluction, the slow downslope movement of water-saturated sediments resulting from the thaw of frozen ground, affected the Arctic Foothills during the $\mathrm{P}-\mathrm{H}$ transition. Today in arctic regions, solifluction accounts for a significant portion of slope denudation (Rapp and
Åkerman, 1993), and it is an important supplier of sediment to streams. In stratigraphic sections, solifluction deposits appear as silty diamictons with elongate clasts that mostly dip downslope at $10-20^{\circ}$ (Nelson, 1985; Elliott and Worsley, 1999). In the Arctic Foothills, solifluction sections are exposed most commonly in stream cutbanks within colluvial basins. Typically in these sections, a layer of deformed peat near the base of the section is overlain by solifluction deposits above an erosional contact. Undisturbed Holocene-aged peats, which often are several meters thick, overlie the solifluction deposits.

We obtained bracketing ${ }^{14} \mathrm{C}$ dates on solifluction deposits in four sections (Fig. 6, Appendix B). At Cobra Gulch, wood mixed with silty diamicton dates to $9740 \pm 70{ }^{14} \mathrm{C} \mathrm{yr} \mathrm{BP}$, and an overlying, horizontally bedded peat dates to $9670 \pm 70{ }^{14} \mathrm{C}$ yr BP. In three other sections, solifluction silts are bracketed between dates of $12,340-8450,10,430-8820$, and $11,560-10,050{ }^{14} \mathrm{C}$ yr BP. At two other sites, the deformed peats underlying solifluction deposits dated to 11,130 (Fig. 6) and $11,350{ }^{14} \mathrm{C}$ yr (East Fork Etivluk River), but no upper limiting dates were found. It is possible that more than one solifluction episode occurred.

In the Arctic, increased solifluction occurs when summer thaw penetrates deeper than usual and melts ice lenses that accumulated previously at the base of the long-term, average active layer (Akerman, 1993). Solifluction can also be enhanced by increased snow cover, which creates higher soil moisture upon melting (Matthews et al., 1993; Elliott and Worsley, 1999). Deeper thawing and increased winter precipitation at the YD/Holocene transition, and possibly during the earlier warm periods of the Lateglacial, are the likely causes of one or more widespread episodes of solifluction in the Arctic Foothills.

\subsection{Fluvial history}

Striking changes in erosional regime and channel planforms occurred in the streams draining the Arctic Foothills between 13,000 and $8000{ }^{14} \mathrm{C}$ yr BP. From at least 12,200 to $\sim 11,000{ }^{14} \mathrm{C} \mathrm{yr} \mathrm{BP}$, streams had braided channels and were aggrading rapidly. Talus buried part of the Lateglacial floodplain of Mesa Creek, a small meandering stream today that heads north of the Brooks Range outside the LGM glacial limit (Fig. 7). Channel fills are preserved at the talus/stream-gravel contact and contain organic debris dating to 11,400 ${ }^{14} \mathrm{C}$ yr BP (Appendix B), indicating that a braided stream had filled the valley with gravel by that time. Similarly, a fill terrace along the East Fork of the Etivluk River is capped by gravel interbedded with peat layers dating to 11,600-11,300 ${ }^{14} \mathrm{C}$ yr BP (Fig. 8). At section N1, the Nigu River had downcut through a valley fill of glacial outwash to near its present level before $12,200{ }^{14} \mathrm{C} \mathrm{yr} \mathrm{BP}$ 

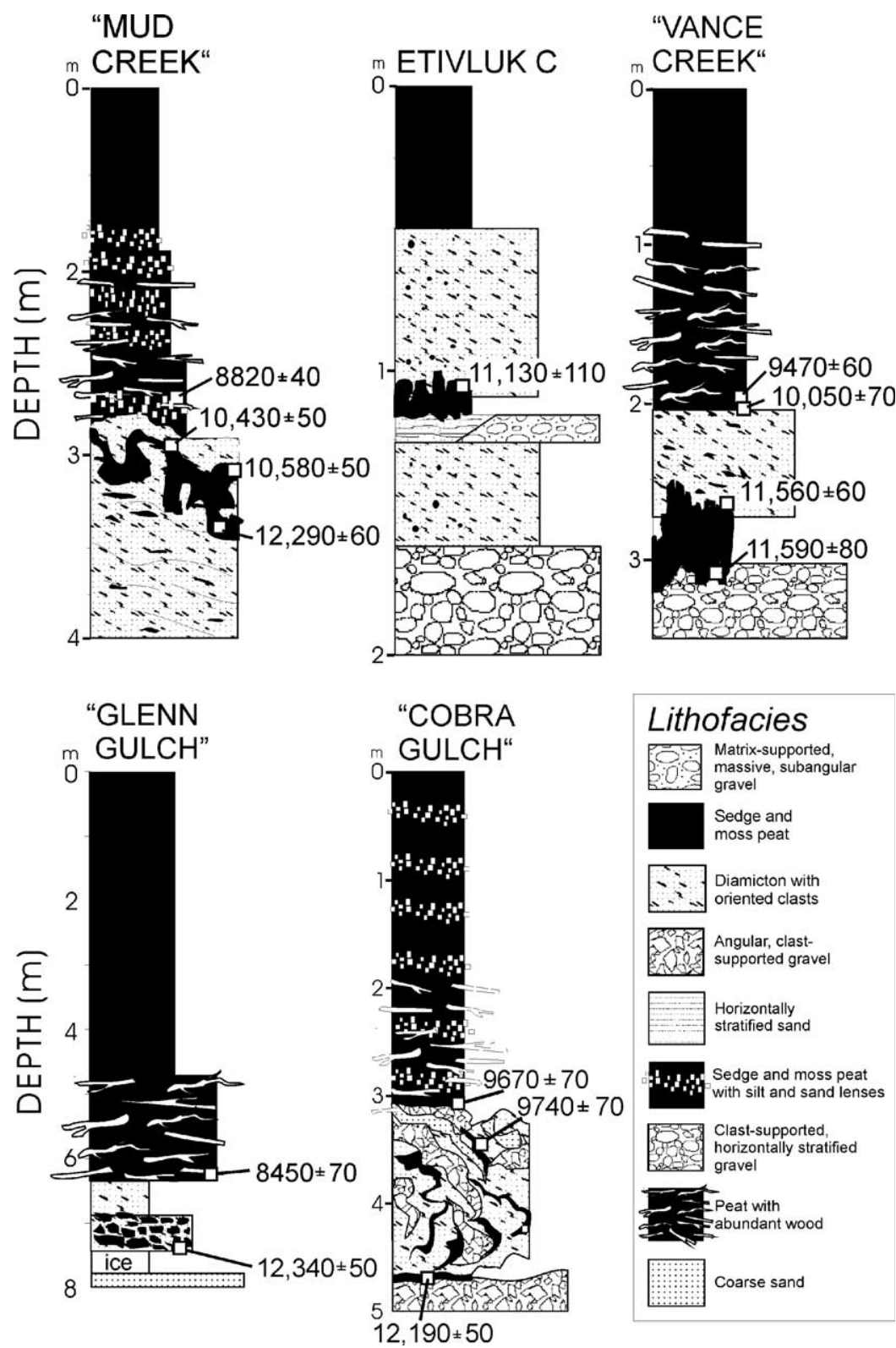

Fig. 6. Stratigraphic evidence for one or more episodes of solifluction that overrode Lateglacial peats around the time of the $\mathrm{P}-\mathrm{H}$ transition.

(Fig. 9). Rapid deposition of gravel containing abundant organic lenses then occurred until $\sim 11,000$ ${ }^{14} \mathrm{C}$ yr BP. At section N2 on the Nigu River, this same period of alluviation is represented by $10 \mathrm{~m}$ of sand interbedded with abundant organic debris. The age of a rooted willow buried in overbank sediments indicates that aggradation ceased there $\sim 10,900{ }^{14} \mathrm{C}$ yr BP.

The upper Ikpikpuk River valley contains well-exposed stratigraphic records of this stream's responses to Lateglacial and early Holocene climatic changes. Organic preservation is exceptional in this low-gradient, sandy stream, and much of the abundant organic debris encountered in sections there is reworked from older, frozen sediments (Nelson and Carter, 1987). For this reason, radiocarbon dates on water-transported plant debris provide maximum-limiting ages only. The most secure age control over fluvial history comes from dates on rooted plants buried in growth position and on aquatic macrophytes found in situ within oxbow-lake sediments.

Rapid alluviation was underway in the Ikpikpuk valley before $11,900{ }^{14} \mathrm{C}$ yr BP and continued until after $11,500{ }^{14} \mathrm{yr} \mathrm{BP}$, as indicated by the ages of willows buried in growth position several meters below the top of Terrace I at Little Supreme Bluff (LSB) (Fig. 10). Comparisons between channel orientations (accretion surfaces) and bedform orientations at LSB suggest that the Ikpikpuk River was braided during this aggradation interval. Bedforms record flow that was oriented $<60^{\circ}$ from the strike of associated channel axes, indicating the prevalence of downstream accretion, which is typical of 

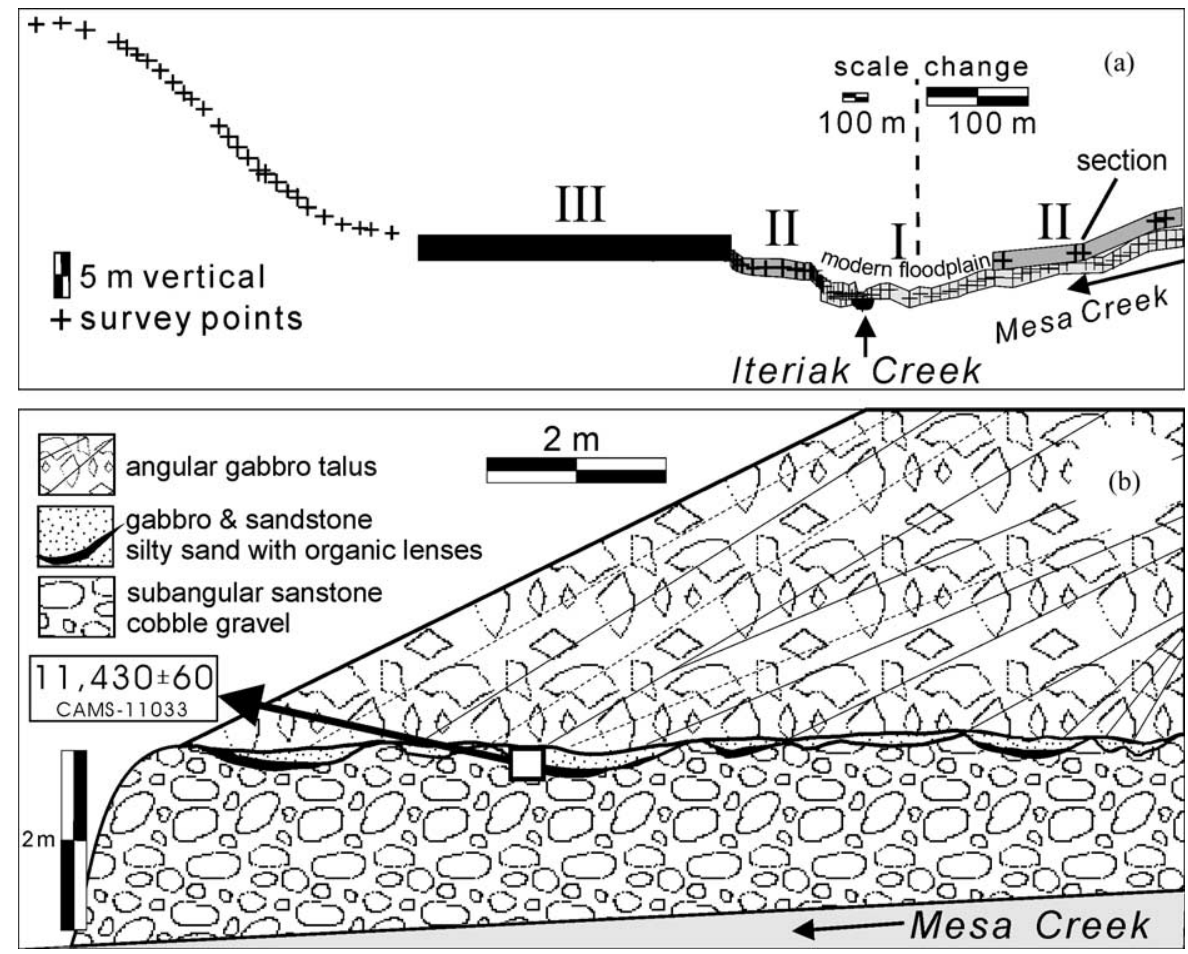

Fig. 7. Leveling transect parallel to lower Mesa Creek and across Iteriak Creek. A Lateglacial fill terrace (II) occurs along both creeks. The higher terrace (III) along Iteriak Creek probably dates to the Last Glacial Maximum. Surface I is the modern floodplain; (b). The surface of a Late Glacial floodplain is preserved at the contact between coarse, sandstone, fluvial gravels and overlying gabbro talus on the southern slope of the Mesa. The AMS- ${ }^{14} \mathrm{C}$ date is from sedge seeds and moss fragments within a channel-fill deposit.
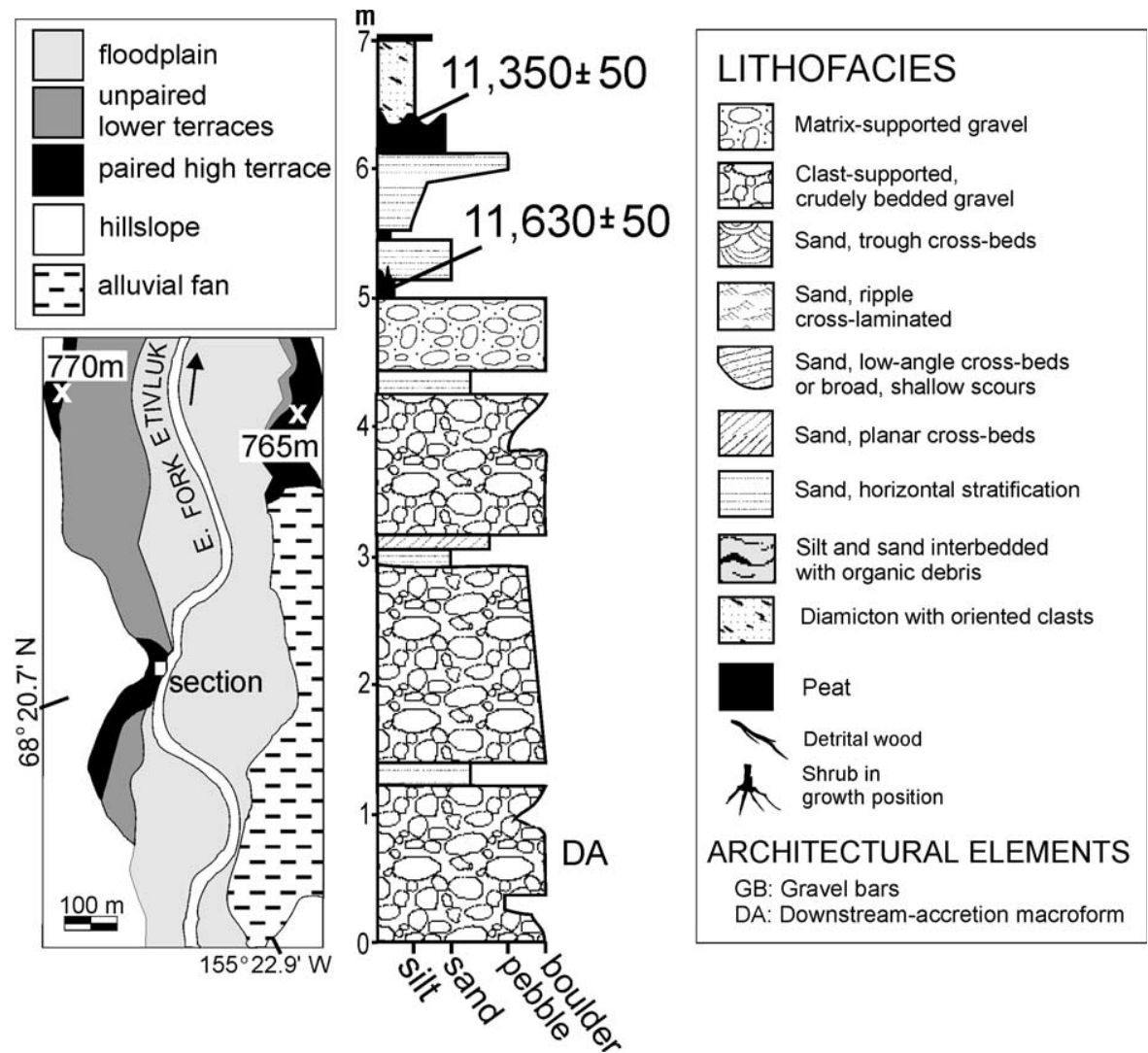

Fig. 8. Section through a fill terrace along the East Fork of the Etivluk River at the northern front of the Brooks Range. The lithofacies key follows Miall (1996). 


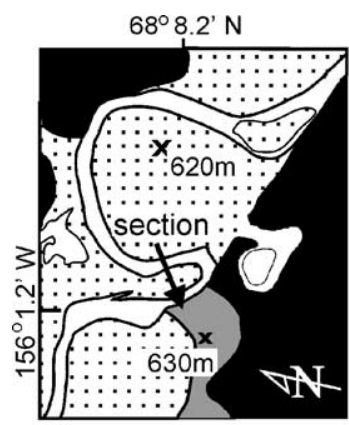

Nigu 2

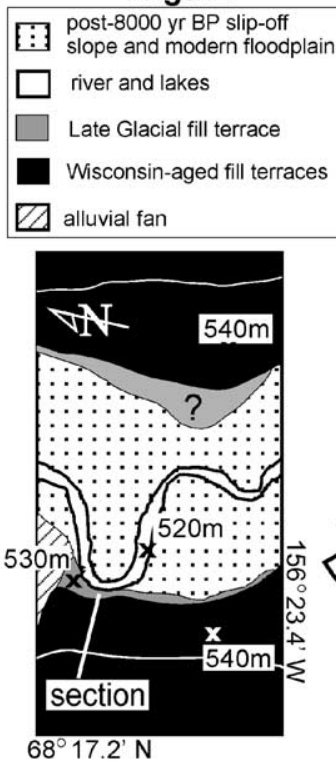

Nigu 1

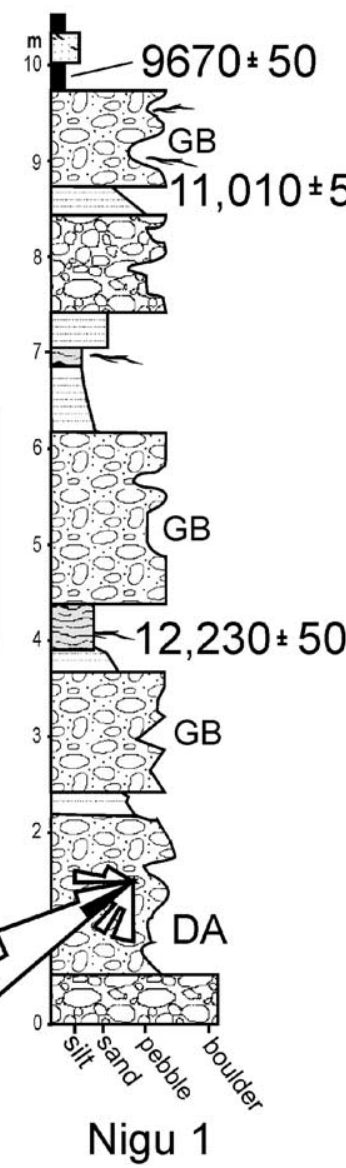

Nigu 1

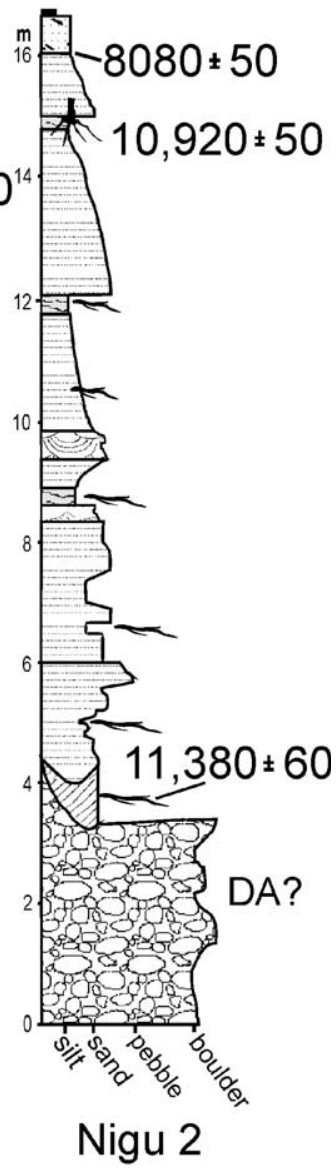

Fig. 9. Sections exposed along the Nigu River. Glacial-age fill terraces are composed of coarse, inorganic sediments and are associated with icemarginal channels, moraines, and kames. The Lateglacial fill terrace is finer grained and contains abundant organic material. The uppermost ${ }^{14} \mathrm{C}$ date in each section is from capping peat. The rose diagram in the Nigu 1 diagram compares the dip directions of accretion surfaces (black) with flow directions inferred from imbricated cobbles (white). DA: downstream accretion macroforms probably deposited during ice retreat from the Last Glacial Maximum. GB: gravel bar of Lateglacial age.

braided channels (Miall, 1996). Only limited areas of Terraces I and II are preserved in the Ikpikpuk valley, making it difficult to infer channel planforms from channel scars on terrace surfaces (e.g., Huisink, 1997).

The Ikpikpuk River began a period of incision sometime before $10,900{ }^{14} \mathrm{C}$ yr BP, which took the river back to within several meters of its present altitude and produced an erosional unconformity marked by a lag of turf blocks. Similar turf blocks, which are quarried from tundra vegetation along cutbanks, are common in the channel today (Fig. 11). The ancient turf blocks at LSB date to $11,700-11,600{ }^{14} \mathrm{C}$ yr BP, but these dates imply only that channel incision and accompanying bluff erosion occurred sometime afterwards. A closer limiting date comes from downstream at Cottonwood Bend. Here a similar channel-lag, also exposed deep inside Terrace II, produced a date of $10,900{ }^{14} \mathrm{C}$ yr BP and indicates that incision occurred after that time (Fig. 12).

At Cottonwood Bend, aggradation resumed after 9700-9100 ${ }^{14} \mathrm{C}$ yr BP, maximum-limiting dates on plant macrofossils contained in the upper $4 \mathrm{~m}$ of this bluff (Fig. 13) (Nelson and Carter, 1987). The Ikpikpuk valley was refilled with sandy sediments to pre-YD levels before $8800-8700{ }^{14} \mathrm{Cyr} \mathrm{BP}$, the ages of emergent, aquatic macrophytes found in the basal sediments of oxbow lakes on Terrace II at both LSB and Cottonwood Bend (Figs. 10 and 12). At LSB, comparisons between channel (i.e., accretion surfaces) and bedform orientations suggest that the Ikpikpuk River was meandering during this early Holocene aggradation interval. In many parts of the section, bedforms record flow oriented $>60^{\circ}$ from the strike of associated channel axes, indicating the predominance of lateral accretion typical of meandering channels (Miall, 1996) (Fig. 10).

Descending series of unpaired terraces in the Arctic Foothills indicate net downcutting after $\sim 8700$ ${ }^{14} \mathrm{C}$ yr BP. Along the Ikpikpuk River, willow shrubs buried in growth positions by fluvial sands indicate that the floodplain was $6-7 \mathrm{~m}$ above its present level between 6070 (site IK3) and $5430{ }^{14} \mathrm{C}$ yr BP (site IK1; Fig. 1). 


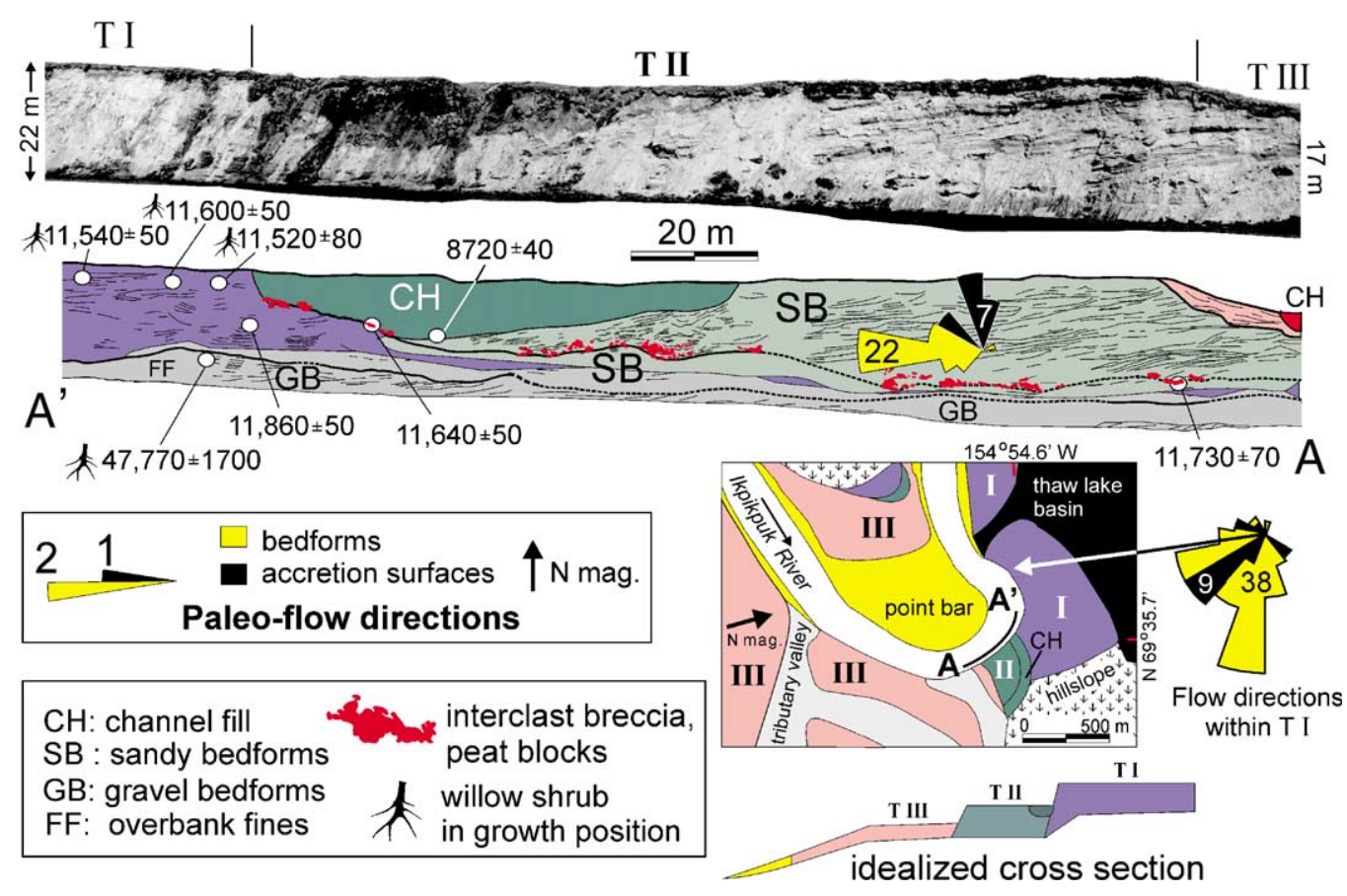

Fig. 10. Photo-mosaic and stratigraphic interpretation of the central part of Little Supreme Bluff, Ikpikpuk River. Different colors in the diagram represent sedimentary units separated by fifth-order bounding surfaces (Miall, 1996). Rose diagrams show dip of accretion surfaces (black) and paleocurrent directions (yellow). DA: downstream-accretion macroforms, LA: lateral-accretion macroforms, FF: floodplain fines, SB: sandy bedforms, GB: gravel bedforms, $\mathrm{CH}$ : channel. Terrace I is remnant from a valley fill emplaced before $\sim 11,000{ }^{14} \mathrm{C}$ yr $\mathrm{BP}$, probably by braided channels. Terrace II is a remnant from a second valley fill deposited by meandering channels in the early Holocene. The 8720 -yr date comes from seeds of the emergent macrophyte, Menyanthes trifoliata, contained in laminated, silty organics at the base of the infilled channel on Terrace II. Menyanthes grows today in oxbow lakes isolated from river flooding. Rose diagrams compare the orientations of small-scale bedforms with larger accretion surfaces.

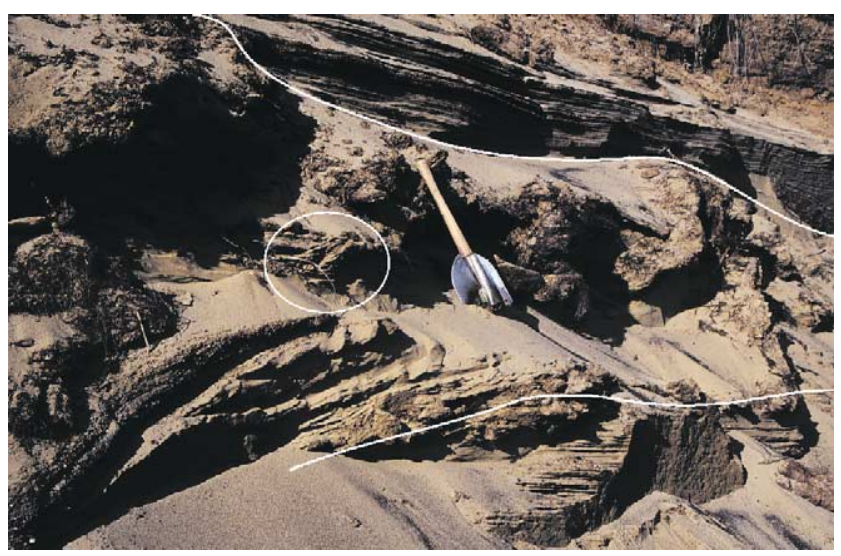

Fig. 11. A lag of peat blocks in ancient channel deposits at Cottonwood Bend, Ikpikpuk River. White lines trace third-order bounding surfaces between lateral-accretion macroforms. Paleo-flow was to the right in direction of peat-block imbrication. A $10,940-\mathrm{yr}{ }^{14} \mathrm{C}$ date came from within the circled area. The entrenching tool is $60 \mathrm{~cm}$ long.

Similarly, at $5010{ }^{14} \mathrm{C}$ yr BP, Iteriak Creek (site IT1) was depositing gravel over willows rooted $2 \mathrm{~m}$ above its modern floodplain.

In summary, fluvial stratigraphy suggests that streams in the Arctic Foothills incised to near their present altitudes sometime before $12,200{ }^{14} \mathrm{C}$ yr BP (Fig. 14). Rapid alluviation occurred from at least 12,200 to $\sim 11,000{ }^{14} \mathrm{C}$ yr BP and was accompanied by braided channels in the Mesa Creek valley and in the Ikpikpuk valley at Little Supreme Bluff. Between $\sim 11,000$ and $\sim 10,000{ }^{14} \mathrm{C}$ yr BP, downcutting occurred. After 10,000 ${ }^{14} \mathrm{C}$ yr BP, valley aggradation resumed and was accompanied by meandering channel planforms near Little Supreme Bluff. Net downcutting began after 8700 ${ }^{14} \mathrm{C}$ yr BP that has continued to the present. These changes occurred in catchments regardless of whether their headwaters were in the Brooks Range or in the Arctic Foothills, eliminating the possibility that glaciers controlled their dynamics (cf., Ashley and Hamilton, 1993; Hamilton, 2001). The fact that the Ikpikpuk River was downcutting during the $\mathrm{YD}$, a time when the Ikpikpuk Dunes were active on the Arctic Coastal Plain (Carter, 1993), indicates that changes in base level caused by dune movements downstream (cf., Loope et al., 1995) did not affect fluvial dynamics at the study sections.

\section{Synthesis}

Data describing multiple biological and geological processes are needed to reconstruct the history of a landscape and its component ecosystems. Besides yielding a better-rounded picture of the paleoenvironment, this approach enables the insensitivities, nonlinear 


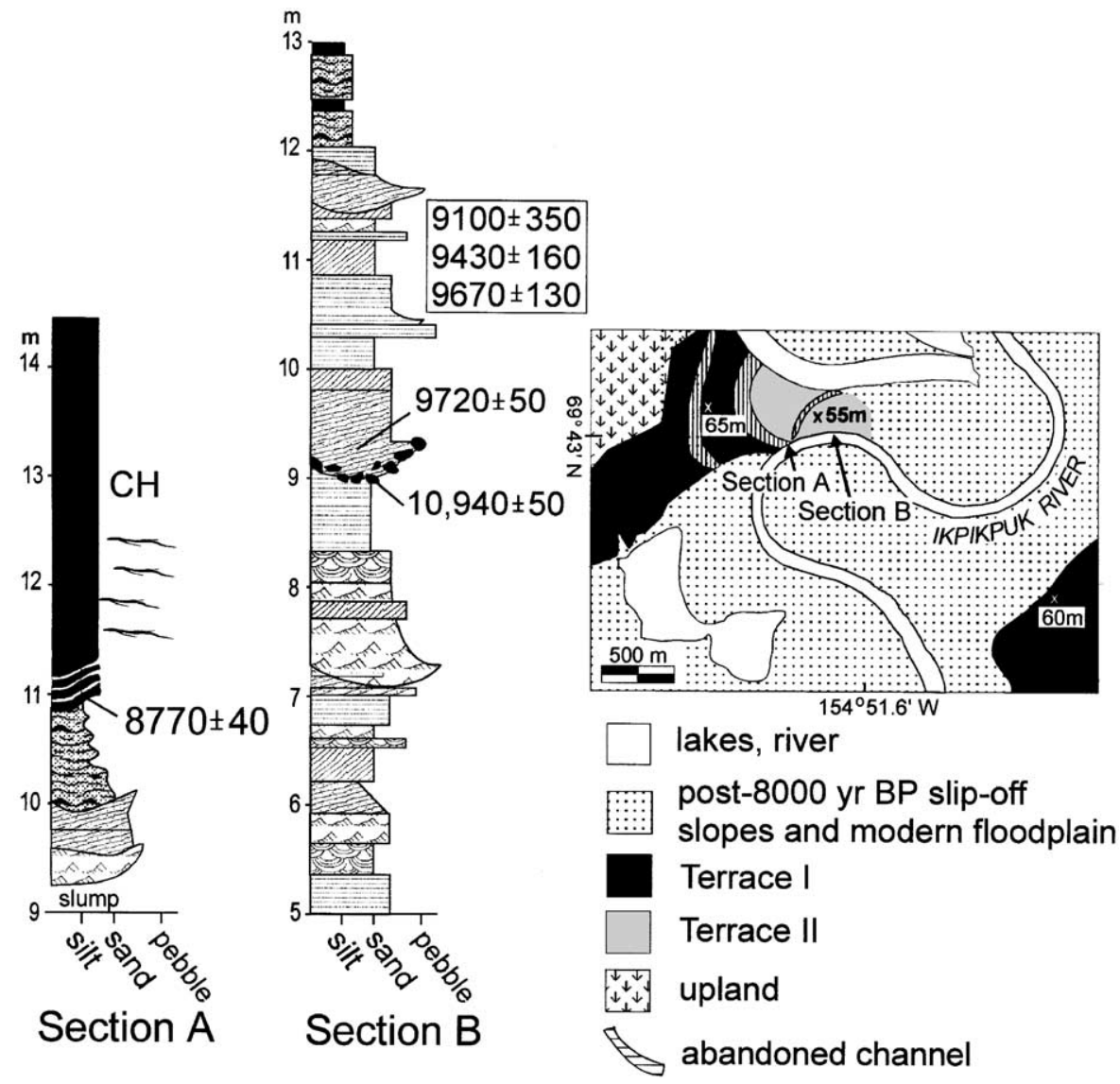

Fig. 12. Stratigraphics sections at Cottonwood Bend, Ikpikpuk River. The two prominent fill terraces here are correlative to Terraces I and II at Little Supreme Bluff based on relative altitude, cross-cutting relationships, and limiting ${ }^{14} \mathrm{C}$ ages. The ${ }^{14} \mathrm{C}$ date in Section A is from Menyanthes trifoliata seeds in silty, graminoid peat at base of an oxbow lake on Terrace II. The boxed ${ }^{14} \mathrm{C}$ dates in Section B are the ages of detrital organics reported by Nelson and Carter (1987). In Section B, the 10,950-yr date is the age of a single poplar leaf from sand infilling the channel-lag shown in Fig. 11. The 9720 -yr date is the age of another single poplar leaf from the overlying channel sands.

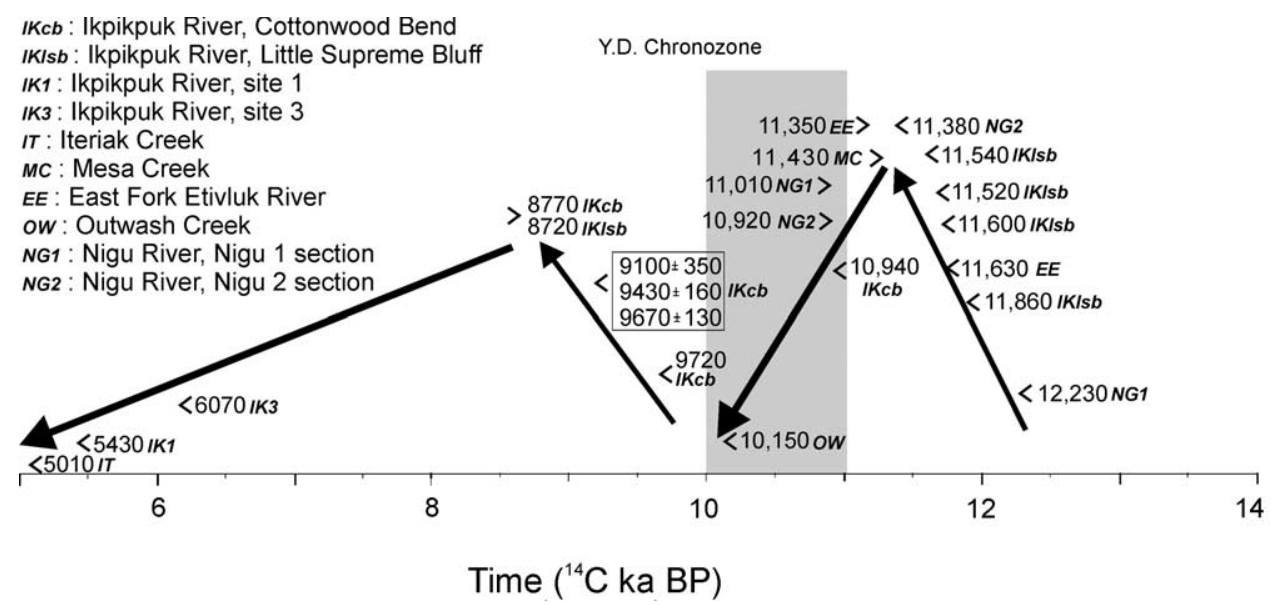

Fig. 13. Limiting ${ }^{14} \mathrm{C}$ dates on fluvial aggradation and incision in the study area. Boxed dates are from Nelson and Carter (1987). The vertical axis is relative height of paleo-floodplains in Ikpikpuk valley.

responses, and missing parts of one record to be tested and corrected by the intact parts of others.

The common theme in the paleo-records described here from the $\mathrm{P}-\mathrm{H}$ transition in the Arctic Foothills is the importance of changes in moisture. The history of lake-level fluctuations indicated by the LOP sections coincides with changes in vegetation, organic-matter accumulation, floodplain dynamics, and solifluction in the surrounding region (Fig. 14). Rising water levels in LOP around $12,500{ }^{14} \mathrm{C}$ yr BP marked the beginning of a period of rapid alluviation by braided streams which lasted until $\sim 11,000{ }^{14} \mathrm{Cyr} \mathrm{BP}$ (Fig. 14). Increased 


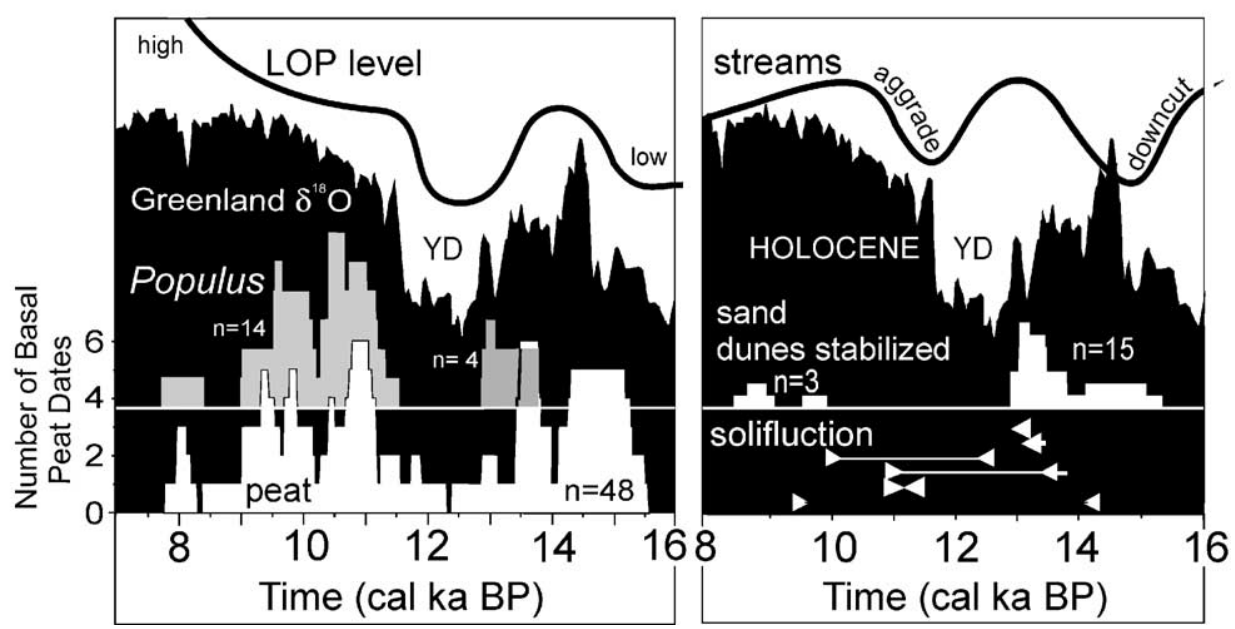

Fig. 14. Synthesis of environmental changes in the Arctic Foothills during the $\mathrm{P}-\mathrm{H}$ transition. The time scale is in calendar years to allow comparison with the Greenland $\delta^{18} \mathrm{O}$ record (Grootes and Stuiver, 1997). The generalized lake-level history is inferred from stratigraphy at LOP. The peat dates are from Appendix C, and the Populus dates from Appendix A. A similar history for Populus emerges from LOP pollen data. The histograms depict the number of ${ }^{14} \mathrm{C}$ dates whose calibrated $1 \mathrm{~L}$ age range falls within a given decade. Dates on stabilization of the Ikpikpuk Dunes are from Carter (1993).

alluviation probably was caused by a combination of increased permafrost melting and heightened hillslope erosion, which perhaps was triggered by increased summer rainfall on a landscape with discontinuous vegetation cover (cf., Cogley and McCann, 1976; Edlund et al., 1989).

Rising water levels in LOP $\sim 12,5000{ }^{14} \mathrm{C}$ yr BP also coincide with the spread of shrub tundra in the Arctic Foothills as indicated by pollen records from LOP and Tukuto Lake (Oswald et al., 1999). At the same time, peat deposition began all across the North Slope (Fig. 14), probably also in response to increasing effective moisture, a well-known trigger for paludification (Moore, 1987; Ovenden, 1990; Gorham, 1991). Prior to $10,000{ }^{14} \mathrm{C}$ yr BP, peat deposition was limited to topographic low points in the Arctic Foothills, suggesting that effective moisture was lower than during the Holocene. Populus trees expanded their range between 12,000 and $11,000{ }^{14} \mathrm{Cyr} \mathrm{BP}$ in response to warmer summers and the wider availability of recently deposited alluvium. The pre-YD occurrence of Populus trees in the Artic Foothills is indicated by ${ }^{14} \mathrm{C}$ dates on wood and a leaf from the Nigu and Ikpikpuk valleys and by the occurence of Populus pollen in the LOP1 section.

Elsewhere in northern and interior Alaska, there also is evidence for a major increase in effective moisture $\sim 12,500{ }^{14} \mathrm{C}$ yr BP. Glaciers in the Brooks Range underwent a minor re-advance between $\sim 13,000$ and $11,500{ }^{14} \mathrm{C}$ yr BP, possibly in response to increasing winter snowfall (Hamilton, 1986). On the Arctic Coastal Plain, the Ikpikpuk dunes became inactive between $\sim 12,500$ and $11,000{ }^{14} \mathrm{C} \mathrm{yr} \mathrm{BP,} \mathrm{most} \mathrm{likely} \mathrm{in} \mathrm{response}$ to increased soil moisture (Carter, 1993). During this same interval in interior Alaska, wetter conditions led to the erosion of extensive gully systems on loess slopes (Hamilton et al., 1988), and water levels at Birch Lake rose more than $18 \mathrm{~m}$ between 12,700 and 12,200 ${ }^{14} \mathrm{C}$ yr BP (Abbott et al., 2000).

During the YD, water levels fell in LOP and paludification slowed in the Arctic Foothills (Fig. 14). Streams incised their floodplains, probably because declining precipitation reduced the input of slope sediments (Fig. 14). Sediment input also may have declined because of reduced solifluction activity and fewer landslides caused by permafrost melting. Populus retracted its distribution in the Arctic Foothills, perhaps in response to cooler summers and to the shrinkage of its floodplain habitat as streams became entrenched. On the Arctic Coastal Plain, dunes were reactivated after $11,000{ }^{14} \mathrm{C}$ yr BP in response to decreased soil moisture (Carter, 1993).

Around $10,000{ }^{14} \mathrm{C}$ yr BP water levels in LOP again rose, and Populus again expanded its distribution in the Arctic Foothills. A brief episode of widespread solifluction occurred, probably in response to the melting of ground ice that had accumulated during the YD. Rapid alluviation resumed in valleys, and this time, at least in the Ikpikpuk valley, channels assumed meandering planforms. This second aggradation episode probably was triggered by intense slope erosion caused by increased summer rains, deeper thawing of soils, and widespread solifluction. In northwestern Canada, numerous thaw lakes developed between 10,000 and 9000 ${ }^{14} \mathrm{Cyr} \mathrm{BP}$ ) in response to an increase in active-layer thickness (Burn et al., 1986; Burn, 1997. Temporary northward extensions of thermophilic plant taxa on the North Slope and in northwestern Canada suggest that 
summer temperatures were higher than today during the earliest Holocene (Ritchie et al., 1983; Nelson and Carter, 1987; Anderson, 1988).

The LOP sections suggest that water levels rose further after $\sim 8600{ }^{14} \mathrm{C}$ yr BP. This is consistent with findings elsewhere in the region. On the Arctic Coastal Plain, increasing soil moisture again stabilized the Ikpikpuk dunes $\sim 8500{ }^{14} \mathrm{C}$ yr BP (Carter, 1993). In interior Alaska, water levels at Birch Lake rose markedly between 8800 and $8000{ }^{14} \mathrm{Cyr} \mathrm{BP}$ (Abbott et al., 2000; Edwards et al., 2001).

The LOP pollen record suggests that the modern vegetation of the Arctic Foothills, along with its poorly drained, peaty soils, probably was established between 9000 and $8500{ }^{14} \mathrm{C}$ yr BP. Other pollen records from the North Slope (Eisner and Peterson, 1998; Oswald et al., 1999) are consistent with this interpretation. The widespread establishment of organic soil horizons was a major turning point for ecosystem history in the Arctic Foothills. Soil temperatures must have fallen and soil moisture risen because of the insulating and waterholding properties of the organic horizons (Bockheim et al., 1998). These same organic surface horizons restricted the frost heaving of mineral material and reduced soil erosion, thus depriving streams of sediment inputs and forcing them into a long-term trend of floodplain incision. As floodplains narrowed and became vegetated, the rate of loess deposition in downwind areas slowed, probably enhancing soil acidification and promoting further paludification (Walker and Everett, 1991).

It is obvious that many natural processes in the Arctic are controlled by temperature. It is less obvious that moisture plays a crucial role in determining the impacts of climatic change there. Moisture is important in mediating the impacts of climatic change in the Arctic for several reasons, some of which are unique to high latitudes. First, atmospheric circulation patterns and the low saturation vapor pressure of cold air restrict precipitation in polar regions (Walsh et al., 1994). Second, the amount and phase state of water at the often-frozen tundra surface determine surface energy budgets to a greater extent than they do at lower latitudes (Kane, 1996). Third, permafrost and seasonally frozen soils create a hydrologic setting where the availability of liquid water is seasonally limited (Hinzman et al., 1996). Consequently, small changes in the timing of thaw or of liquid precipitation can have large effects on land surface processes and vegetation. Fourth, the presence of permafrost makes paludification possible within this relatively dry environment, and paludification triggers powerful feedbacks between soil moisture, soil temperature, soil disturbance, and vegetation cover (Zoltai and Tarnocai, 1975; Moore, 1987). Finally, fluvial activity controls the areal extent of the active floodplains where loess originates. Loess influences soil genesis, vegetation, and possibly herbivore populations in downwind areas (Walker and Everett, 1991; Walker et al., 2001).

The inherent sensitivity of arctic ecosystems to changing moisture conditions, combined with the large shifts in water balance that occurred during the $\mathrm{P}-\mathrm{H}$ transition, made water a key factor in determining the impacts of climate change on landscapes in the Arctic Foothills. During the last glacial maximum, northern Alaska was much drier than today because atmospheric circulation patterns were more zonally oriented, the Polar Front was shifted further south, and lowered sea levels greatly increased climatic continentality (Hamilton et al., 1993; Abbott et al., 2000; Edwards et al., 2001; Guthrie, 2001). Effective precipitation increased rapidly as postglacial sea-levels flooded the broad continental shelves of central Beringia and brought moist, cloudy, maritime climates back to the region. Our results indicate that changes in moisture were the proximate causes for ecosystem-wide responses to climate change in the Arctic Foothills at the end of the last ice age and that they will be again in the future.

\section{Acknowledgements}

We thank C. and C. Adkins, L. Plug, K. Tae, P. Heiser, E. Dillingham, J. Chase, J. Dubét, T. Reanier, S. Durand, and H. Macdonald for their help in the field. A. Krumhardt and D. Hood provided invaluable laboratory support. D. Murray, C. Parker, and A. Batten helped with macrofossil identifications. D. Hopkins, D. Walker, V. Haynes, and T. Hamilton provided valuable discussions. The Bureau of Land Management's Mesa Site Archaeological Research Project and the National Park Service's Shared Beringian Heritage Program supported this research.

\section{Appendix A}

Radiocarbon ages of extralimital Populus subfossils in northern Alaska and northwestern Canada are given in Table 1.

\section{Appendix B}

Radiocarbon ages from lake of the pleistocene, solifluction sections, and fluvial sections described in this study (Table 2).

\section{Appendix C}

Radiocarbon ages of basal peats and buried organics on the North Slope (Table 3). 
Table 1

\begin{tabular}{|c|c|c|c|c|c|}
\hline \multirow[t]{2}{*}{$\begin{array}{l}\text { Laboratory } \\
\text { number }\end{array}$} & Location & \multirow[t]{2}{*}{ Dated material } & \multirow[t]{2}{*}{$\begin{array}{l}\delta{ }^{13} \mathrm{C} \\
(\%)\end{array}$} & \multirow[t]{2}{*}{$\begin{array}{l}{ }^{13} \mathrm{C} \text {-adjusted } \\
\text { radiocarbon age } \\
\text { (yr before } \\
1950 \mathrm{AD} \text { ) }\end{array}$} & \multirow[t]{2}{*}{$\begin{array}{l}1 \sigma \text { calibrated } \\
\text { age range }(\mathrm{cal} \mathrm{yr} \\
\text { before } 1950 \mathrm{AD})^{\text {a }}\end{array}$} \\
\hline & Long $\left({ }^{\circ} \mathrm{W}\right)$ & & & & \\
\hline \multicolumn{6}{|c|}{ Ikpikpuk River (this study) } \\
\hline Beta-109676 & $\begin{array}{l}\text { "Cottonwood Bend" } \\
69^{\circ} 43^{\prime}, 154^{\circ} 52^{\prime}\end{array}$ & Leaf of Populus balsamifera & -29.2 & $10,940 \pm 50^{\mathrm{b}}$ & $13,100-12,880$ \\
\hline Beta-111032 ${ }^{\mathrm{b}}$ & $\begin{array}{l}\text { "Cottonwood Bend" } \\
69^{\circ} 47^{\prime}, 154^{\circ} 48^{\prime}\end{array}$ & Leaf of Populus balsamifera & -31.8 & $9720 \pm 50^{\mathrm{b}}$ & $11,200-11,120$ \\
\hline Beta-120018 & $\begin{array}{l}\text { "Dune Bend" } \\
69^{\circ} 43^{\prime}, 154^{\circ} 52^{\prime}\end{array}$ & Populus log & -26.9 & $9350 \pm 60$ & $10,670-10,430$ \\
\hline Beta-121113 & $\begin{array}{l}\text { "Cottonwood Bend" } \\
69^{\circ} 43^{\prime}, 154^{\circ} 53^{\prime}\end{array}$ & Populus log & -29.6 & $9270 \pm 60$ & $10,560-10,290$ \\
\hline \multicolumn{6}{|c|}{ Ikpikpuk River (Nelson and Carter, 1987) } \\
\hline $\mathrm{I}-11280$ & $69^{\circ} 48.9^{\prime}, 154^{\circ} 24.73^{\prime}$ & $\begin{array}{l}\text { Peat containing Populus balsamifera } \\
\text { leaves }\end{array}$ & - & $9540 \pm 160$ & $11,170-10,580$ \\
\hline I-13174 & $69^{\circ} 43^{\prime}, 154^{\circ} 53^{\prime}$ & Populus wood & - & $9430 \pm 160$ & $11,070-10,428$ \\
\hline I-11282 & $69^{\circ} 35.8^{\prime}, 154^{\circ} 54.5^{\prime}$ & Populus wood & - & $9380 \pm 150$ & $11,040-10,290$ \\
\hline I-13324 & $69^{\circ} 17.5^{\prime}, 154^{\circ} 42.5^{\prime}$ & Populus wood & - & $8710 \pm 140$ & $10,110-9540$ \\
\hline \multicolumn{6}{|c|}{ Northern Alaska and Northwestern Canada (Hopkins et al., 1981) } \\
\hline GSC-1514 & $\begin{array}{l}\text { Twin lakes near Inuvik, } \\
\text { Northwest Territories }\end{array}$ & Populus wood & - & $11,500 \pm 160$ & $13,800-13,180$ \\
\hline $\mathrm{W}-1254$ & $\begin{array}{l}\text { East shore of Kotzebue Sound, } \\
\text { southeast of Riley's Wreck }\end{array}$ & Populus wood & - & $11,340 \pm 400$ & $13,810-12,970$ \\
\hline I-10274 & $\begin{array}{l}\text { West Bank of Nigu River, } \\
11 \mathrm{~km} \text { north of Inyorurak Pass } \\
\text { (probably this paper's Nigu } \\
1 \text { section) }\end{array}$ & Populus wood & - & $11,100 \pm 170$ & $13,180-12,910$ \\
\hline GSC-2022 & $\begin{array}{l}\text { Coastal bluffs southeast of } \\
\text { Sabine Point, Yukon Territory }\end{array}$ & Populus wood & - & $9940 \pm 90$ & $11,550-11,230$ \\
\hline $1-11073$ & lkpikpuk River, Arctic Foothills & Populus wood & - & $9670 \pm 130$ & $11,200-10,750$ \\
\hline $\mathrm{W}-2620$ & $\begin{array}{l}\text { Seward Peninsula between Rex } \\
\text { Point and Cape Deceit }\end{array}$ & Populus wood & - & $9625 \pm 350$ & $11,340-10,430$ \\
\hline W-1255 & $\begin{array}{l}\text { East side of Cape Blossom, } \\
\text { Kotzebue Sound }\end{array}$ & Populus wood & - & $9020 \pm 400$ & $10,670-9550$ \\
\hline W-1249 & $\begin{array}{l}\text { East shore of Kotzebue Sound } \\
\text { at Arctic Circle }\end{array}$ & Populus wood & - & $8550 \pm 400$ & $10,160-9030$ \\
\hline W-1993 & $\begin{array}{l}\text { Sagavanirtok River valley, } \\
\text { northern Alaska }\end{array}$ & Populus wood & - & $8400 \pm 300$ & $9680-9010$ \\
\hline $\mathrm{W}-1250$ & $\begin{array}{l}\text { North side of Cape Blossom, } \\
\text { Kotzebue Sound }\end{array}$ & Populus wood & - & $7270 \pm 350$ & $8410-7740$ \\
\hline
\end{tabular}

${ }^{\mathrm{a}}$ Using Calib4 (Stuiver et al., 1998).

${ }^{\mathrm{b}}$ AMS date. 
Table 2

\begin{tabular}{|c|c|c|c|c|c|c|}
\hline \multirow[t]{2}{*}{ Sample/Location ${ }^{\mathrm{a}}$} & \multirow[t]{2}{*}{$\begin{array}{l}\text { Laboratory } \\
\text { number }\end{array}$} & Location & \multirow[t]{2}{*}{ Dated material } & \multirow[t]{2}{*}{$\begin{array}{l}\delta^{13} \mathrm{C} \\
(\% / o o)\end{array}$} & \multirow{2}{*}{$\begin{array}{l}{ }^{13} \mathrm{C} \text {-adjusted } \\
\text { radiocarbon } \\
\text { age }(\mathrm{yr} \text { before } \\
1950 \mathrm{AD})\end{array}$} & \multirow{2}{*}{$\begin{array}{l}1 \sigma \text { callibrated } \\
\text { age range } \\
(\text { cal yr before } \\
1950 \mathrm{AD})^{\mathrm{b}}\end{array}$} \\
\hline & & $\begin{array}{l}\text { Long } \\
\text { (W) }\end{array}$ & & & & \\
\hline \multicolumn{7}{|l|}{ Ikpikpuk River } \\
\hline $\begin{array}{l}\text { 7-12-97a, } \\
\text { Howard Hill }\end{array}$ & Beta-111035 & $69^{\circ} 25^{\prime}, 154^{\circ} 47^{\prime}$ & $\begin{array}{l}\text { Willow in growth } \\
\text { position }^{\mathrm{c}}\end{array}$ & -30.7 & $5430 \pm 60$ & $6290-6120$ \\
\hline $\begin{array}{l}\text { 7-16-99a, } \\
\text { middle reaches }\end{array}$ & Beta-132694 & $69^{\circ} 39^{\prime}, 154^{\circ} 50^{\prime}$ & Willow in growth position & -26.1 & $6070 \pm 80$ & $7140-6760$ \\
\hline $\begin{array}{l}\text { 7-14-99Q1, } \\
\text { "Cottonwood Bend" }\end{array}$ & Beta-132693 & $69^{\circ} 43^{\prime}, 154^{\circ} 532^{\prime}$ & $\begin{array}{l}\text { Seeds of Menyanthes } \\
\text { trifoliata }\end{array}$ & -27.1 & $8770 \pm 40$ & $9910-9690$ \\
\hline $\begin{array}{l}\text { Ikpikpop1, } \\
\text { "Cottonwood Bend" }\end{array}$ & Beta-109676 & $69^{\circ} 43^{\prime}, 154^{\circ} 52^{\prime}$ & Poplar leaf & -29.2 & $10,940 \pm 50$ & $13,100-12,880$ \\
\hline $\begin{array}{l}\text { Ikpikpop2, } \\
\text { "Cottonwood Bend" }\end{array}$ & Beta-111032 & & Poplar leaf & -31.8 & $9720 \pm 50$ & $11,200-11,120$ \\
\hline $\begin{array}{l}\text { 7-13-99a, Little } \\
\text { Supreme Bluff }\end{array}$ & Beta-132631 & $69^{\circ} 36^{\prime}, 154^{\circ} 55^{\prime}$ & $\begin{array}{l}\text { Seeds of Menyanthes } \\
\text { trifoliata }\end{array}$ & -25.4 & $8720 \pm 40$ & $9880-9560$ \\
\hline $\begin{array}{l}\text { 7-14-99d, Little } \\
\text { Supreme Bluff }\end{array}$ & Beta-132692 & $69^{\circ} 36^{\prime}, 154^{\circ} 55^{\prime}$ & $\begin{array}{l}\text { Willow in growth } \\
\text { position }^{c}\end{array}$ & -27.3 & $11,520 \pm 80$ & $13,790-13,410$ \\
\hline $\begin{array}{l}\text { 7-14-99a, Little } \\
\text { Supreme Bluff }\end{array}$ & Beta-132632 & $69^{\circ} 36^{\prime}, 154^{\circ} 55^{\prime}$ & $\begin{array}{l}\text { Willow in growth } \\
\text { position }^{c}\end{array}$ & -28.3 & $11,540 \pm 50$ & $13,790-13,430$ \\
\hline $\begin{array}{l}\text { 7-1-98c, Little } \\
\text { Supreme Bluff }\end{array}$ & Beta-120023 & $69^{\circ} 36^{\prime}, 154^{\circ} 55^{\prime}$ & $\begin{array}{l}\text { Willow in growth } \\
\text { position }^{c}\end{array}$ & -26.4 & $11,600 \pm 50$ & $13,800-13,450$ \\
\hline $\begin{array}{l}\text { 7-1-98a, Little } \\
\text { Supreme Bluff }\end{array}$ & Beta-120022 & $69^{\circ} 36^{\prime}, 154^{\circ} 55^{\prime}$ & Stick cf willow ${ }^{\mathrm{c}}$ & -27.4 & $11,640 \pm 50$ & $13,820-13,460$ \\
\hline $\begin{array}{l}\text { 7-1-98q, Little } \\
\text { Supreme Bluff }\end{array}$ & Beta-120024 & $69^{\circ} 36^{\prime}, 154^{\circ} 55^{\prime}$ & Stick cf willow & -29.1 & $11,730 \pm 70$ & $13,840-13,500$ \\
\hline $\begin{array}{l}\text { 7-1-98x, Little } \\
\text { Supreme Bluff }\end{array}$ & Beta- 120025 & $69^{\circ} 36^{\prime}, 154^{\circ} 55^{\prime}$ & Stick cf willow & -27.8 & $11,860 \pm 50$ & $14,040-13,660$ \\
\hline $\begin{array}{l}\text { 7-18-98c, Little } \\
\text { Supreme Bluff }\end{array}$ & Beta-123316 & $69^{\circ} 36^{\prime}, 154^{\circ} 55^{\prime}$ & $\begin{array}{l}\text { Willow in growth } \\
\text { position }^{\text {c }}\end{array}$ & -29.0 & $47,770 \pm 1700$ & - \\
\hline \multicolumn{7}{|l|}{ "Mesa Creek" } \\
\hline July93d1 & Beta-69896 & $68^{\circ} 25^{\prime}, 155^{\circ} 48^{\prime}$ & Sedge seeds, moss & -34.6 & $11,430 \pm 60$ & $13,760-13,180$ \\
\hline \multicolumn{7}{|l|}{ Nigu River } \\
\hline 24June98f, Section 1 & Beta- 120020 & $68^{\circ} 8^{\prime}, 156^{\circ} 1^{\prime}$ & Sedge stem & -26.8 & $8080 \pm 50$ & $9030-9000$ \\
\hline 24June98e, Section 1 & Beta- 121110 & & $\begin{array}{l}\text { Willow in growth } \\
\text { position }^{\text {b }}\end{array}$ & -26.1 & $10,920 \pm 50$ & $13,010-12,880$ \\
\hline 24June98a, Section 1 & Beta-120019 & & Stick cf. willow ${ }^{\mathrm{b}}$ & -30.1 & $11,380 \pm 60$ & $13,460-13,170$ \\
\hline $\begin{array}{l}\text { 9June97kin-d, } \\
\text { Section } 2\end{array}$ & Beta-124782 & $68^{\circ} 17^{\prime}, 156^{\circ} 24^{\prime}$ & Twig of birch & -27.5 & $9670 \pm 50$ & $11,170-10,890$ \\
\hline $\begin{array}{l}\text { 9June97kinC, } \\
\text { Section } 2\end{array}$ & Beta-111127 & & Stick cf. willow ${ }^{\mathrm{b}}$ & -28.0 & $11,010 \pm 50$ & $13,140-12,900$ \\
\hline 7-13-98b, Section 2 & Beta-120537 & & Stick cf. willow ${ }^{\mathrm{b}}$ & -29.2 & $12,230 \pm 50$ & $15,230-14,110$ \\
\hline \multicolumn{7}{|l|}{ Iteriak Creek } \\
\hline $7-22-98 \mathrm{~h}$ & Beta-121111 & $68^{\circ} 36^{\prime}, 155^{\circ} 46^{\prime}$ & Stick cf. willow ${ }^{\mathrm{b}}$ & -28.2 & $5010 \pm 80$ & $5890-5650$ \\
\hline \multicolumn{7}{|l|}{ East Fork Etivluk River } \\
\hline 17July97b1 & Beta-111036 & $68^{\circ} 21^{\prime}, 155^{\circ} 23^{\prime}$ & Sedge seeds & -28.2 & $11,350 \pm 50$ & $13,440-13,160$ \\
\hline 17July97b5 & Beta-108257 & & Twig cf. birch & -27.7 & $11,630 \pm 50$ & $13,810-13,460$ \\
\hline \multicolumn{7}{|c|}{ "Lake of the Pleistocene" } \\
\hline LOP $1-\mathrm{j}$ & Beta-97512 & $68^{\circ} 36^{\prime}, 156^{\circ} 16^{\prime}$ & Twig of birch or willow & -30.2 & $4900 \pm 60$ & $5660-5590$ \\
\hline LOP1-f & Beta-97511 & & Twig of birch or willow & -30.2 & $8360 \pm 70$ & $9470-9280$ \\
\hline LOP1-e & Beta-97510 & & Twig of birch or willow & -30.5 & $8530 \pm 70$ & $9450-9490$ \\
\hline LOP1-d & Beta-97509 & & Twig of birch or willow & -29.0 & $8870 \pm 60$ & $10,150-9790$ \\
\hline $7-21-98 \mathrm{~d} 3$ & Beta-122124 & & Twig of birch or willow & -28.0 & $9020 \pm 50$ & $10,220-10,180$ \\
\hline LOP1-c & Beta-97508 & & Twig of birch or willow & -30.5 & $9570 \pm 60$ & $11,110-10,700$ \\
\hline $7-21-98 d 3$ & Beta-121105 & & Twig of birch or willow & -28.8 & $10,240 \pm 50$ & $12,300-11,760$ \\
\hline $7-21-98 \mathrm{c} 2$ & Beta-120539 & & Twig of birch or willow & -29.2 & $10,270 \pm 50$ & $12,320-11,770$ \\
\hline
\end{tabular}


Table 2 (continued)

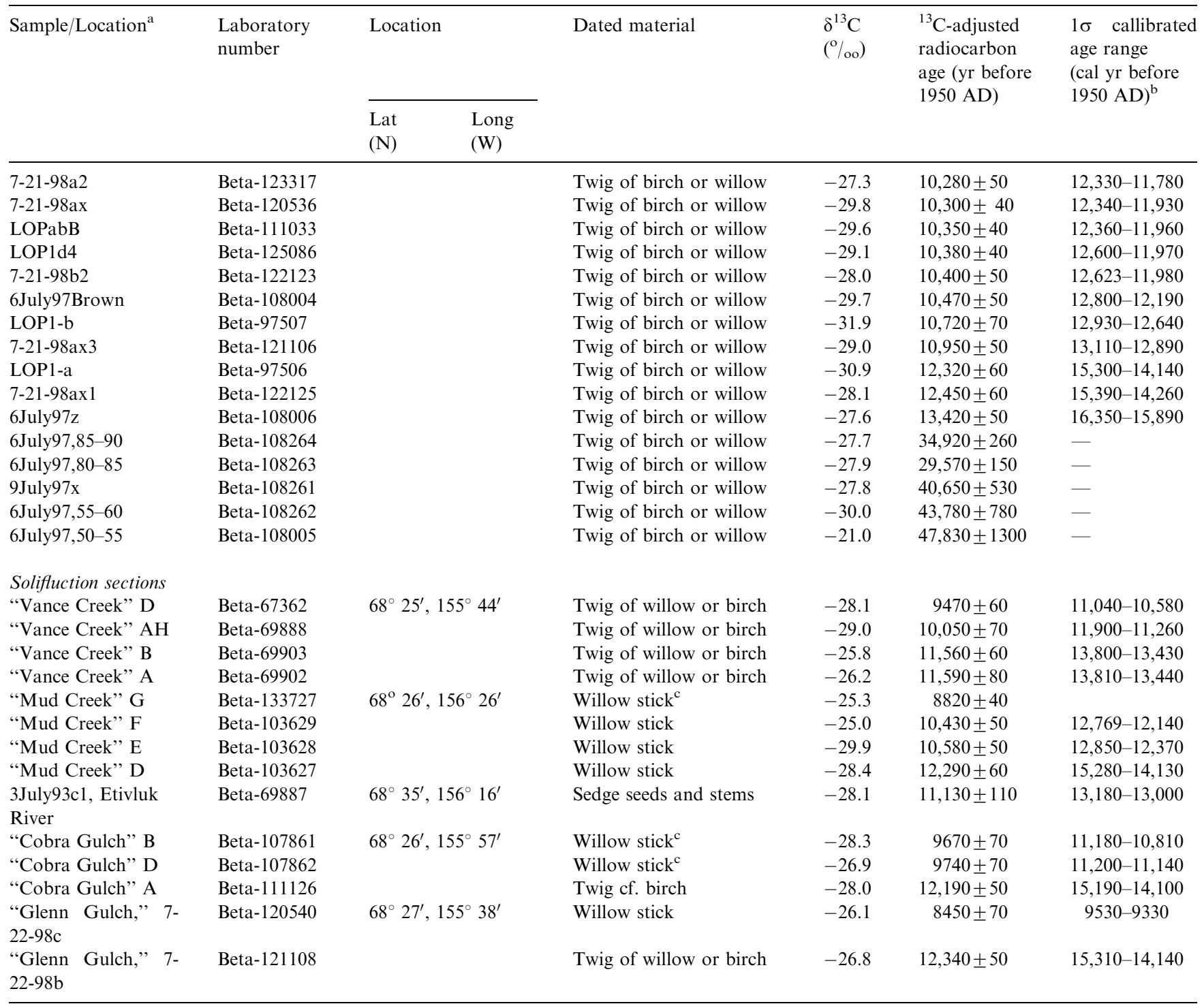

${ }^{\mathrm{a}}$ Informal place names in quotes.

${ }^{\mathrm{b}}$ Using Calib4 (Stuiver et al., 1998).

${ }^{\mathrm{c}}$ Dated by conventional radiometric techniques using liquid scintillation. Others by the AMS technique.

Table 3

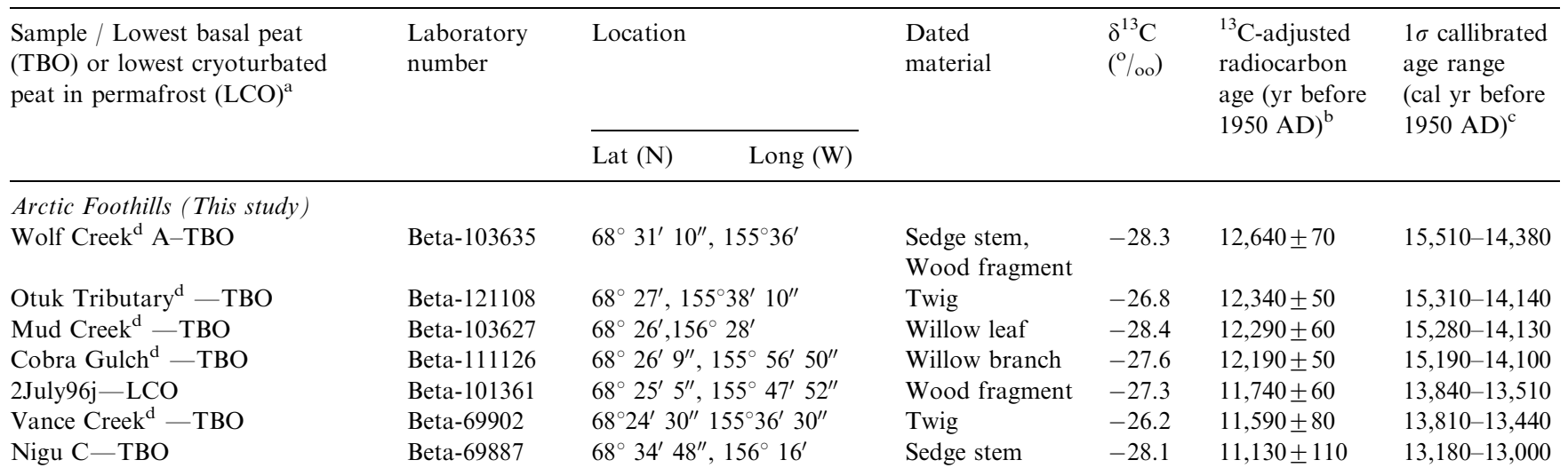


Table 3 (continued)

\begin{tabular}{|c|c|c|c|c|c|c|}
\hline \multirow{2}{*}{$\begin{array}{l}\text { Sample / Lowest basal peat } \\
(\mathrm{TBO}) \text { or lowest cryoturbated } \\
\text { peat in permafrost (LCO) }\end{array}$} & \multirow{2}{*}{$\begin{array}{l}\text { Laboratory } \\
\text { number }\end{array}$} & Location & \multirow{2}{*}{$\begin{array}{l}\text { Dated } \\
\text { material }\end{array}$} & \multirow{2}{*}{$\begin{array}{l}\delta^{13} \mathrm{C} \\
(\%)\end{array}$} & \multirow{2}{*}{$\begin{array}{l}{ }^{13} \mathrm{C} \text {-adjusted } \\
\text { radiocarbon } \\
\text { age }(\mathrm{yr} \text { before } \\
1950 \mathrm{AD})^{\mathrm{b}}\end{array}$} & \multirow{2}{*}{$\begin{array}{l}1 \sigma \text { callibrated } \\
\text { age range } \\
(\text { cal yr before } \\
1950 \mathrm{AD})^{\mathrm{c}}\end{array}$} \\
\hline & & Long (W) & & & & \\
\hline 2July96e-LCO & Beta-101357 & $68^{\circ} 24^{\prime} 52^{\prime \prime}, 155^{\circ} 46^{\prime} 53^{\prime \prime}$ & Wood fragment & -27.2 & $11,020 \pm 60$ & $13,140-12,900$ \\
\hline 2July96f - LCO & Beta-101358 & $68^{\circ} 24^{\prime} 53^{\prime \prime}, 155^{\circ} 46^{\prime} 59^{\prime \prime}$ & Sedge stem & -28.5 & $10,240 \pm 60$ & $12,310-11,760$ \\
\hline $\begin{array}{l}\text { 4July93a } \\
\text { (Vance Creek }^{\mathrm{d}} \text { auger hole) - TBO }\end{array}$ & Beta-69888 & $68^{\circ} 24^{\prime} 30^{\prime \prime}, 155^{\circ} 36^{\prime} 30^{\prime}$ & Twig & -29.0 & $10,050 \pm 70$ & $11,900-11,260$ \\
\hline Cobra Gulch ${ }^{\mathrm{d}}-\mathrm{TBO}$ & Beta-107861 & $68^{\circ} 26^{\prime} 9^{\prime \prime}, 155^{\circ} 56^{\prime} 50^{\prime \prime}$ & Twig & -28.3 & $9670 \pm 70$ & $11,180-10,810$ \\
\hline Vance Creek $^{\mathrm{d}}-\mathrm{TBO}$ & Beta- 67362 & $68^{\circ} 24^{\prime} 30^{\prime \prime}, 155^{\circ} 36^{\prime} 30^{\prime \prime}$ & Twig & -28.1 & $9470 \pm 60$ & $11,040-10,580$ \\
\hline Grayling Gulch $^{\mathrm{d}}-\mathrm{TBO}$ & Beta-103632 & $68^{\circ} 34^{\prime} 48^{\prime \prime}, 156^{\circ} 16^{\prime}$ & Birch twig & -30.4 & $9310 \pm 50$ & $10,580-10,420$ \\
\hline 14July93b-LCO & Beta-69891 & $68^{\circ} 24^{\prime}, 155^{\circ} 48^{\prime} 3^{\prime \prime}$ & Twig & -26.7 & $8830 \pm 100$ & $10,150-9700$ \\
\hline Otuk Tributary $^{\mathrm{d}}-\mathrm{TBO}$ & Beta- 120540 & $68^{\circ} 27^{\prime}, 155^{\circ} 38^{\prime} 10^{\prime \prime}$ & Twig & -26.1 & $8450 \pm 70$ & $9530-9330$ \\
\hline 16July93d-LCO & Beta-69894 & $68^{\circ} 24^{\prime} 33^{\prime \prime}, 155^{\circ} 47^{\prime} 10^{\prime \prime}$ & Twig & -28.3 & $8400 \pm 60$ & $9490-9330$ \\
\hline 16July93a-LCO & Beta-69892 & $68^{\circ} 24^{\prime} 33^{\prime \prime}, 155^{\circ} 47^{\prime} 10^{\prime \prime}$ & Sedge stem & -27.9 & $8260 \pm 90$ & $9430-9030$ \\
\hline 16July93b - LCO & Beta-69893 & $68^{\circ} 24^{\prime} 33^{\prime \prime}, 155^{\circ} 47^{\prime} 10^{\prime \prime}$ & Sedge stem & -27.6 & $7750 \pm 140$ & $8640-8390$ \\
\hline Wolf Creek ${ }^{\mathrm{d}} \mathrm{B}-\mathrm{TBO}$ & Beta-103626 & $68^{\circ} 31^{\prime} 10^{\prime \prime}, 155^{\circ} 36^{\prime}$ & Sedge stem & -25.0 & $7210 \pm 50$ & $8110-7960$ \\
\hline 14July93c-LCO & Beta-67360 & $68^{\circ} 24^{\prime} 40^{\prime \prime}, 155^{\circ} 48^{\prime} 7^{\prime \prime}$ & Twig & -27.2 & $7090 \pm 80$ & $7970-7790$ \\
\hline 2July96c-LCO & Beta-101355 & $68^{\circ} 24^{\prime} 36^{\prime \prime}, 155^{\circ} 46^{\prime} 27^{\prime \prime}$ & Betula twig & -28.9 & $5200 \pm 60$ & $5990-5910$ \\
\hline 2July96h-LCO & Beta-101359 & $68^{\circ} 25^{\prime}, 155^{\circ} 47^{\prime} 49^{\prime \prime}$ & Twig & -25.9 & $4900 \pm 50$ & $5660-5590$ \\
\hline 2July96L-LCO & Beta-101363 & $68^{\circ} 24^{\prime \prime} 41^{\prime \prime}, 155^{\circ} 47^{\prime} 60^{\prime \prime}$ & Betula bark & -29.2 & $3990 \pm 50$ & $4520-4410$ \\
\hline 14July93aa-LCO & Beta-69890 & $68^{\circ} 24^{\prime}, 155^{\circ} 48^{\prime} 3^{\prime \prime}$ & Sedge stem & -30.2 & $3600 \pm 60$ & $3980-3780$ \\
\hline 2July96d-LCO & Beta-101356 & $68^{\circ} 24^{\prime} 36^{\prime \prime}, 155^{\circ} 46^{\prime} 27^{\prime \prime}$ & Betula twig & -28.3 & $3320 \pm 50$ & $3630-3470$ \\
\hline 2July96i-LCO & Beta- 101360 & $68^{\circ} 24^{\prime} 58^{\prime \prime}, 155^{\circ} 47^{\prime} 23^{\prime \prime}$ & Betula twig & -29.2 & $2280 \pm 60$ & $2350-2160$ \\
\hline 2July96m-LCO & Beta-101364 & $68^{\circ} 29^{\prime} 36^{\prime \prime}, 155^{\circ} 46^{\prime} 51^{\prime \prime}$ & Betula twig & -30.8 & $2150 \pm 50$ & $2300-2060$ \\
\hline 2July96b-LCO & Beta-101354 & $68^{\circ} 24^{\prime} 36^{\prime \prime}, 155^{\circ} 46^{\prime} 36^{\prime \prime}$ & Betula twig & -27.9 & $2130 \pm 50$ & $2290-2010$ \\
\hline 2July96k-LCO & Beta-101362 & $68^{\circ} 24^{\prime} 40^{\prime \prime}, 155^{\circ} 48^{\prime} 7^{\prime \prime}$ & Betula twig & -29.8 & $1170 \pm 60$ & $1170-990$ \\
\hline \multicolumn{7}{|l|}{ North Slope (Previous studies) } \\
\hline \multicolumn{7}{|l|}{ Wind River } \\
\hline Hamilton (1982) & I-10715 & $68^{\circ} 49^{\prime}, 149^{\circ} 17.5^{\prime}$ & Sedge peat & - & $9460 \pm 150$ & $11,090-10,430$ \\
\hline Toolik River-TBO & & & Peat & - & $11,700 \pm 180$ & $14,000-13,450$ \\
\hline East Fork Etivlik River-TBO & I-11,419 & - & Peat & - & $11,500 \pm 140$ & $13,800-13,190$ \\
\hline Hinzman et al. (1991) & - & - & & & & \\
\hline \multicolumn{7}{|l|}{ Imnavait Creek-TBO } \\
\hline Carter (1993) & I-11600 & $69^{\circ} 1^{\prime} 18^{\prime \prime}, 151^{\circ} 56^{\prime} 42^{\prime \prime}$ & Wood & - & $11,800 \pm 170$ & $14,060-13,500$ \\
\hline \multicolumn{7}{|l|}{ Ikpikpuk Dunes-TBO } \\
\hline$-\mathrm{TBO}$ & I-12177 & $70^{\circ} 25^{\prime} 42^{\prime \prime}, 152^{\circ} 34^{\prime} 14^{\prime \prime}$ & Peat & - & $11,700 \pm 180$ & $14,000-13,450$ \\
\hline$-\mathrm{TBO}$ & USGS-448 & $70^{\circ} 22.4^{\prime}, 153^{\circ} 12^{\prime} 12^{\prime \prime}$ & Peat & - & $8180 \pm 75$ & $9270-9020$ \\
\hline$-\mathrm{TBO}$ & I-10887 & $70^{\circ} 22^{\prime} 24^{\prime \prime}, 153^{\circ} 12^{\prime} 12^{\prime \prime}$ & Peat & - & $8660 \pm 150$ & $9890-9530$ \\
\hline$-\mathrm{TBO}$ & I-11420 & $70^{\circ} 22^{\prime} 24^{\prime \prime}, 153^{\circ} 12^{\prime} 12^{\prime \prime}$ & Peat & - & $8010 \pm 130$ & $9060-8640$ \\
\hline$-\mathrm{LCO}$ & Beta-5384 & $70^{\circ} 4^{\prime} 21^{\prime \prime}, 151^{\circ} 22^{\prime} 54^{\prime \prime}$ & Peat & - & $9330 \pm 90$ & $10,670-10,290$ \\
\hline$-\mathrm{LCO}$ & Beta-5383 & $70^{\circ} 4^{\prime} 21^{\prime \prime}, 151^{\circ} 22^{\prime} 54^{\prime \prime}$ & Peat & - & $9600 \pm 100$ & $11,170-10,700$ \\
\hline Everett and Brown (1982) & DIC-706 & - & Organic matter & - & $7330 \pm 95$ & $8280-7980$ \\
\hline Sagwon-LCO & & & Over gravel & & & \\
\hline$-\mathrm{LCO}$ & DIC-707 & - & $\begin{array}{l}\text { organic matter } \\
\text { over gravel }\end{array}$ & - & $8860 \pm 125$ & $10,180-9710$ \\
\hline $\begin{array}{l}\text { Ping, C.-L. (written } \\
\text { communication, 1999) }\end{array}$ & GX-20889 & $70^{\circ} 16^{\prime \prime}$ & Peat & -29.2 & $7300 \pm 70$ & $8180-7980$ \\
\hline Arctic Coastal Plain-LCO & & & & & & \\
\hline $\begin{array}{l}\text { Schell and Zieman (1983) } \\
\text { - TBO }\end{array}$ & - & $70^{\circ} 31^{\prime \prime}, 149^{\circ} 6^{\prime}$ & Peat & -28.3 & 8430 est. 200 & $9630-9090$ \\
\hline$-\mathrm{TBO}$ & - & $70^{\circ} 33^{\prime}, 149^{\circ} 24^{\prime}$ & Peat & -28.7 & 9050 est. 200 & $10,500-9790$ \\
\hline$-\mathrm{TBO}$ & I-6839 & $70^{\circ} 31^{\prime}, 149^{\circ} 19^{\prime}$ & Peat & - & 12,610 est. 200 & $15,560-14,290$ \\
\hline$-\mathrm{TBO}$ & $\mathrm{I}-6838$ & $70^{\circ} 31^{\prime}, 149^{\circ} 52^{\prime}$ & Peat & - & 8550 est. 200 & $9890-9300$ \\
\hline ‘Arctic Coastal Plain’—-TBO & - & - & Peat & -27.2 & 9805 est. 200 & $11,560-10,760$ \\
\hline
\end{tabular}

${ }^{\mathrm{a}} \mathrm{TBO}$ and LCO terms explained in text.

${ }^{\mathrm{b}}$ All ages in this table are AMS dates except Beta-111126.

${ }^{\mathrm{c}}$ Using Calib4 (Stuiver et al., 1998).

${ }^{\mathrm{d}}$ Informal place name. 


\section{References}

Abbott, M.B., Stafford, T.W., 1996. Radiocarbon geochemistry of modern and ancient arctic lake systems, Baffin Island, Canada. Quaternary Research 45, 300-311.

Abbott, M.B., Finney, B.P., Edwards, M.E., Kelts, K.R., 2000. Lakelevel reconstructions and paleohydrology of Birch Lake, Central Alaska, based on seismic reflection profiles and core transects. Quaternary Research 53, 154-166.

Åkerman, H.J., 1993. Solifluction and creep rates 1972-1991, Kapp Linne, West Spitsbergen, In: Frenzel, B., Matthews, J.A., Gläser, B., (Eds.), Solifluction and Climatic Variation in the Holocene. Gustav Fischer Verlag, New York, USA, pp. 225-250.

Anderson, P.M., 1985. Late Quaternary vegetational change in the Kotzebue Sound area, northwestern Alaska. Quaternary Research 24, 307-321.

Anderson, P.M., 1988. Late Quaternary pollen records from the Kobuk and Noatak River drainages, northwestern Alaska. Quaternary Research 29, 263-276.

Anderson, P.M., Brubaker, L.B., 1986. Modern pollen assemblages from northern Alaska. Review of Palaeobotany and Palynology 46, 273-291.

Anderson, P.M., Brubaker, L.B., 1994. Vegetation history of northcentral Alaska: a mapped summary of Late-Quaternary pollen data. Quaternary Science Reviews 13, 71-92.

Anderson, P.M., Bartlein, P.J., Brubaker, L.B., 1994. Late Quaternary history of tundra vegetation in northwestern Alaska. Quaternary Research 41, 306-315.

Arnborg, L., Walker, H.J., Peippo, J., 1966. Water discharge in the Colville River, 1962. Geografiska Annaler 48A, 195-210.

Ashley, G.M., Hamilton, T.D., 1993. Fluvial response to late Quaternary climatic fluctuations, central Kobuk valley, northwestern Alaska. Journal of Sedimentary Petrology 63, 814-827.

Bacon, S., 1998. Decadal variability in the outflow from the Nordic seas to the deep Atlantic Ocean. Nature 394, 871-873.

Bartlein, P.J., Edwards, M.E., Shafer, S.L., Barker, E.D., 1995. Calibration of radiocarbon ages and the interpretation of paleoenvironmental records. Quaternary Research 44, 417-424.

Bartlein, P.J., Anderson, K.H., Anderson, P.M., Erdwards, M.E., Mock, C.J., Thompson, R.S., Webb, R.S., Webb, T., Whitlock, C., 1998. Paleoclimatic simulations for North America over the past 21,000 years: features of the simulated climate and comparisons with paleoenvironmental data. Quaternary Science Reviews 17, 549-585.

Bigelow, N.H., Edwards, M.E., 2001. A 14,000 yr paleoenvironmental record from windmill Lake, central Alaska: Late-glacial and Holocene vegetation in the Alaska Range. Quaternary Science Reviews 20, 203-215.

Björck, S., Kromer, B., Johnsen, S., Bennike, O., Hammarlund, D., Lendahl, G., Possnert, G., Rasmussen, T.L., Wohlfarth, B., Hammer, C.U., Spurk, M., 1996. Synchronized terrestrial-atmospheric deglacial records around the North Atlantic. Science 274, $1155-1160$.

Bridgland, D.R., 2000. River terrace systems in north-west Europe: an archive of environmental change, uplift and early human occupation. Quaternary Science Reviews 19, 1293-1303.

Brubaker, L.B., Garfinkel, H.L., Edwards, M.E., 1983. A late Wisconsin and Holocene vegetation history from the central Brooks Range: implications for Alaskan paleoecology. Quaternary Research 20, 194-214.

Bockheim, J.G., Walker, D.A., Everett, L.R., Nelson, F.E., Shiklomanov, N.I., 1998. Soils and cryoturbation in moist nonacidic and acidic tundra in the Kuparuk River basin, arctic Alaska, USA. Arctic and Alpine Research 30, 166-174.
Burn, C.R., 1997. Cryostratigraphy, paleogeography, and climate change during the early Holocene warm interval, western Arctic coast, Canada. Canadian Journal of Earth Sciences 34, 912-925.

Burn, C.R., Michel, F.A., Smith, M.W., 1986. Stratigraphic, isotopic, and mineralogical evidence for an early Holocene thaw unconformity at Mayo, Yukon Territory. Canadian Journal of Earth Sciences 23, 794-803.

Calkin, P.E., 1988. Holocene glaciation of Alaska (and adjoining Yukon Territory, Canada). Quaternary Science Reviews 7, 159184.

Carter, L.D., 1981. A Pleistocene sand sea on the Alaskan arctic coastal Plain. Science 211, 381-383.

Carter, L.D., 1988. Loess and deep thermokarst basins in arctic Alaska. In: Permafrost, Fifth International Conference, Proceedings. Vol. 1, Tapir, Trondheim, Norway, pp. 706-711.

Carter, L.D.,1993. Late Pleistocene stabilization and reactivation of eolian sand in northern Alaska: implications for the effects of future climatic warming on an aeolian landscape in continuous permafrost, In: Proceedings, Sixth International Conference on Permafrost, Vol. 1. Beijing, China: Wushan, Guangzhou, China, South China University Technology Press, pp. 78-83.

Carter, L.D., Heginbottom, J.A., Woo, M-K., 1987. Arctic lowlands, In: Graf, W.L., (Ed.), Geomorphic Systems of North America, Geology of North America, Vol. 2, Geological Society of America, Boulder, Colorado, pp. 583-628.

Chapin, F.S., Shaver, G.S., Giblin, A.E., Nadelhoffer, K.J., 1995. Responses of arctic tundra to experimental and observed changes in climate. Ecology 76, 694-711.

Cogley, J.G., McCann, S.B., 1976. An exceptional storm and its effects in the Canadian high arctic. Arctic and Alpine Research 8, 105110.

Colinvaux, P.A., 1964a. The environment of the Bering Land Bridge. Ecological Monographs 34, 297-325.

Colinvaux, P.A., 1964b. Origin of ice ages: pollen evidence from arctic Alaska. Science 145, 707-708.

Collins, P.E.F., Fenwick, I.M., Keith-Lucas, D.M., Worsley, P., 1996. Late Devensian river and floodplain dynamics and related environmental change in northwest Europe, with particular reference to a site at Woolhampton, Berkshire, England. Journal of Quaternary Science 11, 357-375.

Cwynar, L.C., 1982. A Late-Quaternary vegetation history from Hanging Lake, northern Yukon. Ecological Monographs 52, $1-24$.

Dean, W.E., 1974. Determination of carbonate and organic matter in calcareous sediments and sedimentary rocks by loss on ignition: comparison with other methods. Journal of Sedimentary Petrology 44, 242-248.

Dearing, J.A., 1997. Sedimentary indicators of lake-level changes in the humid temperate zone: a critical review. Journal of Paleoliminology $18,1-14$.

Dinter, D.A., Carter, L.D., Brigham-Grette, J., 1990. Late Cenozoic geologic evolution of the Alaskan north Slope and adjacent continental shelves. In: Grantz, A., Johnson, L., Sweeney, J.F. (Eds.), The Arctic Ocean Region. Geological Society of America. Boulder, pp. 459-490.

Edlund, S.A., Alt, B.T., Young, K., 1989. Interaction of climate, vegetation, and soil hydrology at Hot Weather Creek, Fosheim Peninsula, Ellesmere Island, Northwest Territories. Geological Survey of Canada, Paper 89-1D, pp. 125-133.

Edwards, M.E., Barker, E.D., 1994. Climate and vegetation in northeastern Alaska 18,000 yr. BP-Present. Paleogeography Paleoclimatology Paleoecology 109, 127-135.

Edwards, M.E., Dunwiddie, P.W., 1985. Dendrochronological and palynological observations on Populus balsamifera in northern Alaska. Arctic and Alpine Research 17, 271-278. 
Edwards, M.E., Mock, C.J., Finney, B.P., Barber, V.A., Bartlein, P.J., 2001. Potential analogues for paleoclimatic variations in eastern interior Alaska during the past 14,000 years. Quaternary Science Reviews 20, 189-202.

Eisner, W.R., Colinvaux, P.A., 1990. A long pollen record from Ahaliorak Lake, arctic Alaska. Review of Palaeobotany and Palynology 63, 35-52.

Eisner, W.R., Colinvaux, P.A., 1992. Late Quaternary pollen records from Oil Lake and Feniak Lake, Alaska, USA. Arctic and Alpine Research 24, 56-63.

Eisner, W.R., Peterson, K.M., 1998. High-resolution pollen analysis of tundra polygons from the north slope of Alaska. Journal of Geophysical Research 103, 28,929-28,937.

Elias, S.A., 2000. Late Pleistocene climates of Beringia, based on analysis of fossil beetles. Quaternary Research 53, 229-235.

Elias, S.A., 2001. Mutual climatic range reconstructions of seasonal temperatures based on Late Pleistocene fossil beetle assemblages in Eastern Beringia. Quaternary Science Reviews 20, 77-91.

Elias, S.A., Short, S.K., Nelson, C.H., Birks, H.H., 1996. Life and times of the Bering Land Bridge. Nature 382, 60-63.

Elliott, G., Worsley, P., 1999. The sedimentology, stratigraphy, and ${ }^{14} \mathrm{C}$ dating of a turf-banked solifluction lobe: evidence for Holocene slope instability at Okstindan, northern Norway. Journal of Quaternary Science 14, 175-188.

Epstein, S., 1995. The isotopic climatic records in the Allerød-BøllingYounger Dryas and post-Younger Dryas events. Global Biogeochemical Cycles 9, 557-563.

Everett, K.R., Brown, J., 1982. Some recent trends in the physical and chemical characterization and mapping of tundra soils, Arctic Slope of Alaska. Soil Science 133, 264-280.

Ferrians Jr., O.J, 1994. Permafrost in Alaska. In: Plafker, G., Berg, H.C. (Eds.), The Geology of Alaska. Geological Society of America. Boulder, Colorado, pp. 845-854.

Foley, J.A., Kutzbach, J.E., Coe, M.T., Levis, S., 1994. Feedbacks between climate and boreal forests during the Holocene epoch. Nature 371, 52-54.

Frenzel, B. (Ed.), 1995. European river activity and climatic change during the Lateglacial and early Holocene. Gustav Fischer, Verlag, Stuttgart.

Galloway, J.P., Carter, L.D., 1993. Late Holocene longitudinal and parabolic dunes in northern Alaska: preliminary interpretations of age and paleoclimatic significance. US Geological Survey Bulletin 2068, pp. 3-11.

Gorham, E., 1991. Northern peatlands: role in the carbon cycle and probable responses to climatic warming. Ecological Applications 1, 182-195.

Grantz, A., May, S.D., Hart, P.E., 1994. Geology of the Arctic continental margin of Alaska. In: Plafker, G., Berg, H.C. (Eds.), The Geology of Alaska. Geological Society of America. Boulder, Colorado, pp. 17-48.

Grootes, P.M., Stuiver, M., 1997. Oxygen 18/16 variability in Greenland snow and ice with $10^{3}$ to $10^{5}$-year time resolution. Journal of Geophysical Research 102, 26, 455-26, 470.

Guthrie, R.D., 2001. Origin and causes of the mammoth steppe: a story of cloud cover, wooly mammoth tooth pits, buckles, and inside-out Beringia. Quaternary Science Reviews 20, 549-574.

Hajdas, I., Bonani, G., Bodén, P., Peteet, D.M., Mann, D.H., 1998. Cold reversal on Kodiak Island, Alaska, correlated with the European Younger Dryas using variations of atmospheric ${ }^{14} \mathrm{C}$ content. Geology 26, 1047-1050.

Hamilton, T.D., 1979. Radiocarbon dates and Quaternary stratigraphic sections, Philip Smith Mountains quadrangle, Alaska. US Geological Survey Open-File Report 79-866, 44 pp.

Hamilton, T.D., 1980. Surficial geologic map of the Killik River Quadrangle, Alaska. US Geological Survey Miscellaneous Field Studies Map MF-1234, scale:1:250,000, 1 sheet.
Hamilton, T.D., 1982. Quaternary stratigraphic sections with radiocarbon dates, Killik River quadrangle, Alaska. US Geological Survey Open-file Report 82-606, 32pp.

Hamilton, T.D., 1984. Surficial geologic map of the Howard Pass quadrangle, Alaska. US Geological Survey Miscellaneous Field Studies Map MF-1677, scale 1:250,000, 1 sheet.

Hamilton, T.D., 1986. Late Cenozoic glaciation of the central Brooks Range. In: Hamilton, T.D., Reed, K.M., Thorson, R.M. (Eds.), Glaciation in Alaska. Alaska Geological Society. Anchorage, Alaska, pp. 9-50.

Hamilton, T.D., 2001. Quaternary glacial, lacustrine, and fluvial interactions in the western Noatak Basin, Northwest Alaska. Quaternary Science Reviews 20, 371-391.

Hamilton, T.D., Ashley, G.M., 1993. Epiguruk: a late Quaternary environmental record from northwestern Alaska. Geological Society of America Bulletin 105, 583-602.

Hamilton, T.D., Porter, S.C., 1975. Itkillik glaciation in the Brooks Range, northern Alaska. Quaternary Research 5, 471-497.

Hamilton, T.D., Ashley, G.M., Reed, K.M., Schweger, C.E., 1993. Late Pleistocene vertebrates and other fossils from Epiguruk, Northwestern Alaska. Quaternary Research 39, 381-389.

Hamilton, T.D., Craig, J.L., Sellman, P.V., 1988. The Fox permafrost tunnel: a late Quaternary geologic record in central Alaska. Geological Society of America Bulletin 100, 948-969.

Heathwaite, A.L., Göttlich, E.G., Burmeister, E.G., Kaule, G., Grospietsch, Th., 1993. Mires: definitions and forms. In: Heathwaite, A.L. (Ed.), Mires: Process, Exploitation, and Conservation. Wiley, New York, pp. 1-76.

Hinzman, L.D., Kane, D.L., 1992. Potential response of an arctic watershed during a period of global warming. Journal of Geophysical Research 97, 2811-2820.

Hinzman, L.D., Kane, D.L., Benson, C.S., Everett, K.R., 1996 Energy balance and hydrological processes in an arctic watershed, In: Reynolds, J.F. and Tenhunen, J.D. (Eds.), Landscape Function and Disturbance in Arctic Tundra: Springer New York, pp. 131-152.

Hopkins, D.M., 1959. Some characteristics of the climate in forest and tundra regions of Alaska. Arctic 12, 214-220.

Hopkins, D.M., Kidd, J.G., 1988. Thaw lake sediments and sedimentary environments. In: Permafrost, Fifth International Conference, Proceedings. Vol. 1, Tapir, Trondheim, pp. 790-795.

Hopkins, D.M., Smith, P.A., Matthews, J.V., 1981. Dated wood from Alaska and the Yukon. Implications for forest refugia in Beringia. Quaternary Research 15, 217-249.

Huisink, M., 1997. Late-glacial sedimentological and morphological changes in a lowland river in response to climatic change: the Maas, southern Netherlands. Journal of Quaternary Science 12, 209-223.

Kane, D.L., 1996. The impact of hydrologic perturbations on arctic ecosystems induced by climate change. In: Oechel, W.C., Callaghan, T., Gilmanov, T., Holten, J.I., Maxwell, B., Molau, U., Sveinbjornsson, B. (Eds.), Global Change and Arctic Terrestrial Ecosystems. Springer, New York, pp. 63-81.

Kane, D.L., Hinzman, L.D., Woo, M-K., Everett, K.R., 1992. Arctic hydrology and climate change. In: Chapin, F.S., Jeffries, R.L., Reynolds, J.F., Shaver, G.R., Svoboda, J. (Eds.), Arctic Ecosystems in a Changing Climate, an Ecophysiological Perspective. Academic Press, New York, pp. 35-57.

Kattsov, V.M., Walsh, J.E., 2000. Twentieth-century trends of arctic precipitation from observational data and a climate model simulation. Journal of Climate 13, 1362-1370.

Knox, J.C.,1983. Responses of river systems to Holocene climates, In: Wright, H.E. (Ed.), Late-Quaternary Environments of the United States, Vol. 2, The Holocene. University of Minnesota Press, Minneapolis, pp. 26-41. 
Knox, J.C., 2000. Sensitivity of modern and Holocene floods to climate change. Quaternary Science Reviews 19, 439-457.

Kunz, M.L., Reanier, R.E., 1994. Paleoindians in Beringia: evidence from arctic Alaska. Science 263, 660-662.

Livingstone, D.A., 1957. Pollen analysis of a valley fill near Umiat, Alaska. American Journal of Science 255, 254-260.

Loope, D.B., Swinehart, J.B., Mason, J.P., 1995. Dune-dammed paleovalleys of the Nebraska Sand Hills: intrinsic versus climatic controls on the accumulation of lake and marsh sediments. Geological Society of America Bulletin 107, 396-406.

Lynch, A.H., Chapman, W.L., Walsh, J.E., Weller, G., 1995. Development of a regional climate model of the western Arctic. Journal of Climate 8, 1555-1570.

Macklin, M.G., 1999. Holocene river environments in prehistoric britain: human interaction and impact. Quaternary Proceedings 7, 521-530.

Matthews, J.A., Ballantyne, C.K., Harris, C., McCarroll, D., 1993. Solifluction and Climatic Variation in the Holocene: discussion and synthesis. In: Frenzel, B., Matthews, J.A., Gläser, B. (Eds.), Solifluction and Climatic Variation in the Holocene. Gustav Fischer Verlag, New York, pp. 339-362.

Maxwell, B., 1996. Recent climate patterns in the Arctic. In: Oechel, W.C., Callaghan, T., Gilmanov, T., Holten, J.I., Maxwell, B., Molau, U., Sveinbjornsson, B. (Eds.), Global Change and Arctic Terrestrial Ecosystems. Springer, New York, pp. 21-46.

Miall, A.D., 1996. The Geology of Fluvial Deposits. Springer Verlag, New York.

Moore, T.R., 1987. Thermal regime of peatlands in subarctic eastern Canada. Canadian Journal of Earth Sciences 24, 1352-1359.

Moore, T.R., Roulet, N.T., Waddington, J.M., 1998. Uncertainty in predicting the effect of climatic change on the carbon cycling of Canadian peatlands. Climatic Change 40, 229-245.

Moritz, R.E., 1979. Synoptic Climatology of the Beaufort Sea Coast of Alaska. Occasional Paper Number 30, Institute of Arctic and Alpine Research, University of Colorado, Boulder, Colorado.

Murray, D.F., 1980. Balsam poplar in Alaska. Canadian Journal of Anthropology 1, 29-32.

Murton, J.B., 1996. Thermokarst-lake basin sediments, Tuktoyaktuk Coastlands, western arctic Canada. Sedimentology 43, 737-760.

Nelson, F.E., 1985. A preliminary investigation of solifluction macrofabrics. Catena 12, 23-33.

Nelson, R.E., Carter, L.D., 1987. Paleoenvironmental analysis of insects and extralimital Populus from an early Holocene site on the Arctic Slope of Alaska, USA. Arctic and Alpine Research 19, 230-241.

Nelson, F.E., Lachenbruch, A.H., Woo, M-K., Koster, E.A., Osterkamp, T.E., Gavrilova, M.K., Guodong, C., 1993. Permafrost and changing climate. In: Proceedings, Sixth International Conference on Permafrost, Vol. 1. Beijing, China: Wushan, Guangzhou, China, South China University Technology Press, p. 987-1005.

Newman, J.E., Branton, C.I., 1972. Annual water balance and agricultural development in Alaska. Ecology 53, 513-519.

Oechel, W.C., Vourlitis, G.L., 1996. Climate change in northern latitudes: alterations in ecosystem structure and function and effects on carbon sequestration. In: Oechel, W.C., Callaghan, T., Gilmanov, T., Holten, J.I., Maxwell, B., Molau, U., Sveinbjornsson, B. (Eds.), Global Change and Arctic Terrestrial Ecosystems. Springer, New York, pp. 381-401.

Oswald, W.W., Brubaker, L.B., Anderson, P.M., 1999. Late Quaternary history of the Howard Pass area, northwestern Alaska. Canadian Journal of Botany 77, 570-581.

Ovenden, L., 1990. Peat accumulation in northern wetlands. Quaternary Research 33, 377-386.
Overpeck, J., Hughen, K., Hardy, D., Bradley, R., Case, R., Douglas, M., Finney, B., Gajewski, K., Jacoby, G., Jennings, A., Lamoureux, S., MacDonald, G., Moore, J., Retelle, M., Smith, S., Wolfe, A., Zielinski, G., 1997. Arctic environmental change of the last four centuries. Science 278, 1251-1256.

PALE, 1994. Research protocols for PALE: Paleoclimates from Arctic Lakes and Estuaries. IN PAGES Workshop Report, Series 94-1, Vladivostok, Russia, March 1993. Anderson, P.M. (Ed),. PAGES, Bern, Switzerland.

Patric, J.H., Black, P.E., 1968. Potential evaporation and climate in Alaska by Thornthwaite's classification. United States Department of Agriculture Forest Service Research Paper PNW-71. Pacific Northwest Forest and Range Experimental Station, Institute of Northern Forestry, Juneau, Alaska.

Payette, S., 1993. The range limits of boreal tree species in QuébecLabrador: an ecological and palaeoecological interpretation. Review of Palaeobotany and Palynology 79, 7-30.

Ping, C.L., Bockheim, J.G., Kimble, J.M., Michaelson, G.J., Walker, D.A., 1998. Characteristics of cryogenic soils along a latitudinal transect in arctic Alaska. Journal of Geophysical Research 103, 28,917-28,928.

Porter, S.C., An Zhisheng, Zheng Hongbo, 1992. Cyclic Quaternary alluviation and terracing in a nonglaciated drainage basin on the north flank of the Qinling Shan, central China. Quaternary Research 38, 157-169.

Rapp, A., Akerman, J., 1993. Slope processes and climate in the Abisko Mountains, northern Sweden. In: Frenzel, B., Matthews, J.A., Gläser, B. (Eds.), Solifluction and Climatic Variation in the Holocene. Gustav Fischer Verlag, New York, pp. 163-177.

Ritchie, J.C., Cwynar, L.C., Spear, R.W., 1983. Evidence from northwest Canada for an early Holocene Milankovitch thermal maximum. Nature 305, 126-128.

Rovansek, R.J., Hinzman, L.D., Kane, D.L., 1996. Hydrology of a tundra wetland complex on the Alaska Arctic Coastal Plain, USA. Arctic and Alpine Research 28, 311-317.

Schell, D.M., 1983. Carbon-13 and carbon-14 abundances in Alaskan aquatic organisms: delayed production from peat in arctic food webs. Science 219, 1068-1071.

Schell, D.M., Zieman, P.J., 1983. Accumulation of peat carbon in the Alaska Arctic Coastal Plain and its role in biological productivity, In: Proceedings, Fourth International Conference on Permafrost in Fairbanks, Alaska: Washington, DC, National Academy Press, Washington, DC, pp. 1105-1110.

Scott, K.M., 1978. Effects of permafrost on stream channel behavior in arctic Alaska: US Geological Survey Professional Paper 1068.

Shaver, G.R., Laundre, J.A., Giblin, A.E., Nadelhoffer, K.J., 1996. Changes in live plant biomass, primary production, and species composition along a riverside toposequence in arctic Alaska, USA. Arctic and Alpine Research 28, 363-379.

Sly, P.G., 1978. Sedimentary processes in lakes. In: Lerman, A. (Ed.), Lakes: Chemistry, Geology, Physics. Springer, New York, pp. 65-89.

Stuiver, M., Reimer, P.J., Bard, E., Beck, J.W., Burr, G.S., Hughen, K.A., Kromer, B., McCormac, F.G., v.d. Plicht, J., Spurk, M., 1998. INTCAL98 Radiocarbon Age Calibration, 24,000-0 cal BP. Radiocabon 40, 1041-1083.

Szeicz, J.M., MacDonald, G.M., 2001. Montane climate and vegetation dynamics in easternmost Beringia during the Late Quaternary. Quaternary Science Reviews 20, 247-257.

Tebbens, L.A., Veldkamp, A., Westerhoff, W., Kroonenberg, S.B., 1999. Fluvial incision and channel downcutting as a response to Late-glacial and Early Holocene climate change: the lower reach of the River Meuse (maas), The Netherlands. Journal Quaternary Science 14, 59-75. 
Verschuren, D., 1999. Sedimentation controls on the preservation and time resolution of climate-proxy records from shallow fluctuating lakes. Quaternary Science Reviews 18, 821-837.

Viereck, L.A., 1970. Forest succession and soil development adjacent to the Chena River in interior Alaska. Arctic and Alpine Research $2,1-26$.

Viereck, L.A., Little, E.L., 1975. Atlas of United States Trees, Vol. 2, Alaskan trees and Common Shrubs. US Forest Service Miscellaneous Publication No. 1293, Washington, DC.

Walker, D.A., Everett, K.R., 1991. Loess ecosystems of northern Alaska: regional gradient and toposequence at Prudhoe Bay. Ecological Monographs 6, 437-464.

Walker, D.A., Walker, M.D., 1996. Terrain and vegetation of the Imnavait Creek watershed. In: Reynolds, J.F., Tenhunen, J.D. (Eds.), Landscape Function and Disturbance in Arctic Tundra. Springer, New York, pp. 73-108.

Walker, D.A., Short, S.K., Andrews, J.T., Webber, P.J., 1981. Late Holocene pollen and present-day vegetation, Prudhoe Bay and Atigun River, Alaskan North Slope. Arctic and Alpine Research 13, 153-172.

Walker, D.A., Binnian, E., Evans, B.M., Lederer, N.D., Nordstrand, E., Webber, P.J., 1989. Terrain vegetation and landscape evolution of the R4D research site, Brooks Range Foothills, Alaska. Holarctic Ecology 12, 238-261.
Walker, M.D., Walker, D.A., Auerbach, N.A., 1994. Plant communities of a tussock tundra landscape in the Brooks Range Foothills, Alaska. Journal of Vegetation Science 5, 843-866.

Walker, D.A., Auerbach, N.A., Bockheim, J.G., Chapin, F.S., Eugster, W., King, J.Y., McFadden, J.P., Michaelson, G.J., Nelson, F.E., Oechel, W.C., Ping, C.L., Reeburg, W.S., Regli, S., Shiklomanov, N.I., Vourlitis, G.L., 1998. Energy and trace-gas fluxes across a soil ph boundary in the arctic. Nature 394, 469-472.

Walker, D.A., Bockheim, J.G., Chapin, F.S., Eugster, W., Nelson, F.E., Ping, C.L., 2001. Calcium-rich tundra, wildlife, and the "Mammoth Steppe. Quaternary Science Reviews 20, 149-163.

Walsh, J.E., Zhou, X., Portis, D., Serreze, M.C., 1994. Atmospheric contribution to hydrologic variations in the Arctic. AtmosphereOcean 32, 733-755.

Yershov, E.D., 1998. General Geocryology. Cambridge University Press, Cambridge.

Zhang, T., Osterkamp, T.E., Stamnes, K., 1996. Some characteristics of the climate in northern Alaska, USA. Arctic and Alpine Research 28, 509-518.

Zhang, T., Osterkamp, T.E., Stamnes, K., 1997. Effects of climate on the active layer and permafrost on the North Slope of Alaska, USA. Permafrost and Periglacial Processes 8, 45-67.

Zoltai, S.C., Tarnocai, C., 1975. Perennially frozen peatlands in the western Arctic and Subarctic of Canada. Canadian Journal of Earth Science 12, 28-43. 